\title{
THE LOWER PERMIAN INSECTS OF KANSAS. PART II. THE ORDERS PRO'TORTHOPTERA AND ORTHOPTERA ${ }^{1}$
}

\author{
By F. M. Carpenter \\ Harvard University
}

The two preceding papers in this series dealt with representatives of seven closely related families of the Order Protorthoptera occurring in the Elmo limestone. The present paper treats additional families of more diverse relationships within that order and also covers several families of the Order Orthoptera.

The problems involved in the systematics of the Palaeozoic orthopteroids are intrinsically very great, mainly as a result of our fragmentary knowledge of most species but also as a result of the variability of the venation within species. It was my belief more than twenty years ago (1943, pp. 76-77) that the classification of the Palaeozoic orthopteroids as suggested by Handlirsch first and by Martynov later was not realistic in the light of our knowledge at that time. Since then many additional orthopteroids have been described, mostly from the Lower and Upper Permian strata of the Soviet Union. These new fossils have added greatly to our knowledge of the early history of the orthopteroid complex. Through the courtesy of Dr. B. B. Rohdendorf, Arthropod Section, Palaeontological Institute, Academy of Sciences, in Moscow, I had the opportunity in 1961 of studying both the undescribed and described material in the collection of the Institute; and of discussing with Dr. Sharov, Dr. Martynova, Dr. Bekker-Migdisova and other staff members of the Institute various problems of insect evolution. I would be remiss if I did not acknowledge at this time my gratitude to the entire staff of the Institute for their kindness and help during and subsequent to my stay.

During the past decade I have been able to study additional orthopteroids collected at the Elmo locality and especially in the Midco beds in Oklahoma. Two additional trips to the Institute de Paléontologie in Paris have enabled me to make further examination of the Commentry fossils, which I still consider (in spite of the remarkable fossil insects from Tchekarda in the Soviet Union) the foundation on which our understanding of Palaeozoic insects rests.

\footnotetext{
${ }^{1}$ This research has been supported in part by a National Science Foundation Grant, No. GB 2038.

Part 10 of this series was published in the Proc. Amer. Acad. Arts Sci., $78: 185-219,1950$.
} 
In the present state of our knowledge, the classification of the Palaeozoic orthopteroids is necessarily based on the venation of the fore wings, the hind wings and body structures being very little known at best and entirely unknown in by far the majority of species. Since considerable difference of interpretation exists in even the recent literature on the orthopteroid venation, I consider it necessary to present here my own views on the homologies of wing veins in these particular insects and indeed in insects in general. I find that few students of insects have any understanding of the problems of vein homology or of the current status of the subject. The following account is intended to present the background and the nature of my own views used throughout this paper and the subsequent parts in the series.

Although some preliminary attempt was made by Hagen ( 1870 ) to homologize the wing veins of insects, Redtenbacher ( I886) was the first to make a significant contribution to the subject. He proposed the recognition of six main veins, which he termed the costa, subcosta, radius, media, cubitus and anal. In reaching his conclusions, he considered the general correlation of the positions of the veins, as well as a primitive alternation of topography, i.e., convexity and concavity. The Redtenbacher System of nomenclature was followed by Comstock and is actually the one which has been in general use, although it is commonly referred to as the Comstock-Needham System. ${ }^{2}$ Comstock's first publications on wing veins appeared in 1892. In I895, J. G. Needham, then a graduate student under Comstock, began a new approach to the study of wing vein homology and the ontogenetic development of wings and their veins. Results of these studies were first published in a series of articles under joint authorship of Comstock and Needham in I898 and 1899. An extensive series of papers, mainly by Needham, appeared in subsequent years and in r9i 8 Comstock brought together in book form a compilation of what had been done in his and Needham's laboratories. They concluded that the various patterns of wing venation in insects had been derived from a common ancestral type and that the veins of different orders could be homclogized. The Redtenbacher System of nomenclature was used by them, although no significance was attached to the convexity or concavity of the veins.

As noted above, the innovation brought into their venational studies was the ontogenetic method. Noting that in such primitive insects

\footnotetext{
${ }^{2}$ Comstock himself pointed out $(1918$, p. 11) that this nomenclature should be recognized as the Redtenbacher System, not the Comstock-Needham System.
} 
as the Plecoptera only tracheae could be seen in the developing wings, and that the pattern of venation of the adult wing agreed closely with the pattern of tracheation in the wing pad, they concluded that tracheae determined the positions of the veins (Comstock, I918, p. I2). They also concluded that the ontogenetic history of the tracheal pattern recapitulated the phylogenetic history of the venation in the group of insects concerned. Applying these principles to the Odonata and Ephemeroptera, for example, they reached the unexpected conclusion that a branch of the radius vein had crossed over a branch of the media in the course of the evolution of these groups; the trachea appeared to cross over in the wing pad and this, in their view, meant that the vein had done likewise in previous geologic time. Objections to the tracheation theory of vein determination and especially to the recapitulative conclusions were raised by several students of fossil insects and insect evolution (e.g., Tillyard, Martynov, Carpenter, Fraser) in the period from 1923-1935. In 1935, Needham reiterated his stand on the ontogenetic-phylogenetic relationship of tracheae and veins; and in $195 \mathrm{I}$, he published a more detailed discussion in defense of this thesis, especially as it related to the Odonata, although a substantial part of his paper was an attempt to ridicule in a personal manner all individuals who had disagreed with him. ${ }^{3}$

As Needham himself indicated (1935, p. I29) there had not been undertaken up to that time a thoroughgoing investigation of the development of nymphal wings of any species, at least with respect to the development of tracheae and veins. Shortly after, however, such an investigation was made by Holdsworth (1940, I94I), this consisting of a histological study of the development of wing pads, tracheae and veins, starting with the earliest beginnings of the wing buds. The plecopteran, Pteronarcys, was chosen because Comstock and Needham considered the stone-flies as demonstrating most clearly the tracheal determination of veins. Holdsworth's results were strikingly clear: the tracheae did not enter the main area of the wing pads until the blood spaces or lacunae between the blocks of epidermal cells had already established the positions of the veins. The tracheae, as they grew longer, simply entered the lacunae which had already been blocked out, following the lines of least resistance. Variation in the tracheal branching was obvious and usually several

\footnotetext{
${ }^{3}$ One can only regret that this final paper on this subject by Needham was so vindictive. It contributed nothing to science and detracted from Needham's image as a scientist. It also earned a black mark for the American Entomological Society for publishing it.
} 
lacunae received no tracheae. Eventually, the epidermal cells lining the lacunae, including those without tracheae, secreted the cuticular materials which finally formed the veins. The obvious conclusion from this investigation was that the tracheae did not determine the positions of the veins. What Comstock and Needham had observed was the entrance of the tracheae into the wing pad, followed by vein formation, which ultimately closely resembled the tracheal pattern. What they did not see was that the blood lacunae, along which the veins would form, were already blocked out, before the development and extension of the tracheae.

Holdsworth's conclusions have been corroborated by the investigations of Henke (1953) and of Leston (1962) on the inter-relationships of veins and tracheae, demonstrating that the lacunae in wing pads ate the precursors of veins, the tracheae merely occupying the available lacunae. Smart (r96I) has shown that the cutting of the main tracheae in the wing pad of Periplaneta resulted in degeneration of tracheal branches and in retracheation but with an abnormal pattern, which, however, had no effect on the normal venational pattern. His conclusion was that the pattern of tracheation of the nymphal or the pupal wing could not be taken as fundamental in determining the homologies of the veins. ${ }^{4}$ As the situation now stands, the ComstockNeedham method of determining homologies of veins, which dominated investigations of wings for the first half of the present century, must be regarded as a side issue which actually led nowhere. However, it must also be emphasized that many of the conclusions reached by Comstock and Needham, not involving their ontogenetic method, are perfectly valid.

Another approach to the problem of homologies was introduced by Lameere in I923, as a result of his extended and important studies on the Carboniferous insects of Commentry, France. Impressed by the regularity of the convexities and concavities, he concluded that there were originally two media veins and two cubitus veins, one of each being convex $(+)$ and the other concave $(-)$; these he termed the media anterior (MA), media posterior (MP), cubitus anterior (CUA) and cubitus posterior (CUP). He believed that some insects had both convex and concave elements, while others had various combinations of one or the other. Support for his con-

\footnotetext{
${ }^{4} \mathrm{I}$ have given this detailed summary of the Comstock-Needham method of determining wing homologies because their conclusions, based on this technique, have become firmly implanted in American entomological literature and in current texts. See, for example, the 1963 edition of Borror and Delong's "An Introduction to the Study of Insects."
} 
clusions has come from the study of Palaeozoic insects and more primitive groups of living insects with the result that the Lameere view has been generally accepted as a working hypothesis by students of fossil insects and insect evolution. In this connection, one should recall that Redtenbacher in his original account of vein homologies used the alternation of convexities as part of the evidence for his system of homologies. Unfortunately, the convexity or concavity of several veins has been lost in most orders of insects. The subcosta $(-)$, radius $(+)$, radial sector $(-)$, anterior cubitus $(+)$ and posterior cubitus (-) tend to retain their topography in membranous wings, although virtually all veins in thick tegmina or elytra appear to have lost their topographic positions. The anterior media $(+)$ and posterior media $(-)$ have generally come to lie flat in the wing membrane, except in the palaeopterous orders, where they are distinctly different. As a working hypothesis, I am assuming the presence of both of these veins in the early neopterous stock; there is some evidence from the pattern of these two veins in closely related taxa that they have been retained even in the endopterygote line (see, for example, Carpenter, 1940, Adams, 1958). Histological investigations on the development of convex and concave veins are still needed. Holdsworth included some histological observations in his work previously cited, but his studies were limited to one species. Mayfly wings, treated with caustic potash, separate into their original membranes, all the convex veins being on the dorsal membrane and all the concave veins on the ventral membrane (Speith, I932; Holdsworth, 194I). Holdsworth noted that, although there was not this sharp difference in Pteronarcys, most of the cuticular material of the convex veins appeared to be formed in the dorsal epidermal layer and most of that of the concave veins in the lower epidermal layer. It is not improbable that this is generally the case. As noted above, veins have tended to lose the topographic characteristics in tegmina or elytra; and it is possible that a previously concave vein might eventually acquire a convex position secondarily if the tegmen became membranuus. However, I regarded the latter occurrence as probably a rare event and consider convexities or concavities of veins as due to the original condition, unless strong evidence exists to the contrary.

In my own work on insect evolution, therefore, I use the following terminology for wing veins: costa $(+)$, subcosta $(-)$, radius $(+)$, radial sector $(-)$, anterior media $(+)$, posterior media $(-)$, anterior cubitus $(+)$, posterior cubitus $(-)$, and anals $(+,-$, or flat $)$. The term postcubitus was suggested by Snodgrass 
for the first anal of Comstock and Needham; however, I see no reason to make this change especially since the new name would almost certainly be confused with Lameere's posterior cubitus mentioned above.

\section{Order Protorthoptera}

As noted above, the Palaeozoic orthopteroids present unusual problems in classification. The Blattodea, although part of this phylogenetic complex, are not included in the present discussion, since they are usually regarded as comprising a distinct order. The Manteodea and Phasmatodea are as yet unknown in Palaeozoic strata. We are therefore concerned in this discussion with the living order Orthoptera (i.e., Saltatoria) and with a bewildering variety of orthopteroid fossils, some of which appear to be close to the Orthoptera, but others which are suggestive of the Blattodea, Manteodea, Phasmatodea, Plecoptera, or combinations of two or more of these groups. Unfortunately, our knowledge of about four-fifths of these species is restricted to the fore wings or even to only a part of the fore wings.

Handlirsch ( I906) recognized two main extinct orders in the complex, the Protorthoptera and Protoblattoidea, but found it necessary to recognize a third category, "Protorthoptera vel Protoblattoidea" for the species which he could not clearly assign to one or the other. As more Palaeozoic insects became known, a gradual diminution of the distinctions between the Protorthoptera and Protoblattoidea resulted and the number of genera in the "Protorthoptera vel Protoblattoidea" category became nearly as great as the number in the Protoblattoidea itself. In 1937, Martynov suggested the separation of the several non-saltatorial families into a distinct order, Paraplecoptera, leaving in the Protorthoptera only the saltatorial forms. More recently, this proposal has been amplified and somewhat altered by Sharov, who has suggested additional differences between the Protorthoptera, Protoblattoidea, and Paraplecoptera. This involves the transfer of a few species (Oedischiidae) with well developed jumping hind legs into the true Orthoptera, restricting the Protorthoptera to one family, having an incipient saltatorial modification of the legs, with the bulk of the Palaeozoic orthopteroid families going into the Paraplecoptera and Protoblattoidea.

Before considering Sharov's proposed classification, I wish to discuss certain aspects of the venation of the fore wing of these Orthopteroids, at least those features which involve differences in interpretation. $\mathrm{Sc}, \mathrm{R}$, $, \mathrm{Rs}, \mathrm{CuP}$ and the anals present no difficulties in their homologies, but the media (and to some extent $\mathrm{CuA}$ ) is a 
different matter. In the orthopteroids, as noted above, the media does not show the clear division into a convex anterior branch and a concave posterior one. It is often deeply forked and the posterior branch may be strongly concave or only slightly concave or even neutrai (flat), but I think it can be safely said that there is no orthopteroid known in which the anterior branch of the media is conzex. We have no way of knowing, therefore, whether in such cases the entire media consists only of MP (with a flattened anterior branch) or of MA and MP, with a flattened MA. The only positive criterion by which we can identify a vein in the orthopteroids as homologous with MA of the Palaeoptera is by its convexity - which none have. I think there is enough evidence, however, to justify the probable determination of the anterior branch of $M$ as $M A$ in some families of orthopteroids, but the determination is only a working hypothesis. ${ }^{5}$

Another area of controversy is the relationship between $\mathrm{CuA}$ and $M$. In the majority of the orthopteroids there is some type of connection between $\mathrm{M}$ and $\mathrm{CuA}$, if only a short cross-vein. In others (as Stereopteridae, figures IO-I3 of the present paper), $\mathrm{CuA}$ curves upwards and fuses with part of $M$ before diverging off as an independent vein. It should be noted that there is marked individual variation in the nature and amount of this coalescence. In others, such as the Blattinopsidae, there is a strongly convex stem of $M$ (see figures 7 and $\delta$ of this paper) which become abruptly flat or concave after the divergence of a short, convex, posterior branch. I think it probable here that the anterior branch of $\mathrm{CuA}$ is fused with $M$ from the very base until the point of divergence. A somewhat similar situation appears to occur in the Oedischiidae and related families (these being treated here as true Orthoptera), but I believe

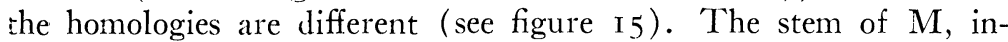
stead of being markedly convex, is flat or even concave. The short vein which diverges towards $\mathrm{CuA}$ is rather weak in the Oedischiidae, although it may be stronger in other, related families. In this case,

\footnotetext{
${ }^{5}$ In my own descriptive accounts of the Paleozoic orthopteroids I use the designation MA and MP if the posterior branch is definitely concave and the anterior branch flat; if the posterior branch is flat like the anterior one $I$ use the designation $M$ for the entire system; if all branches of the media are concave, I use the designation MP for all.

Explanation of Plate 4

Lemmatophora typa Sellards. Photograph of specimen No. 3539, Museum of Comparative Zoology, showing prothoracic lobes, with hair covering and reticulated pattern. Original.
} 


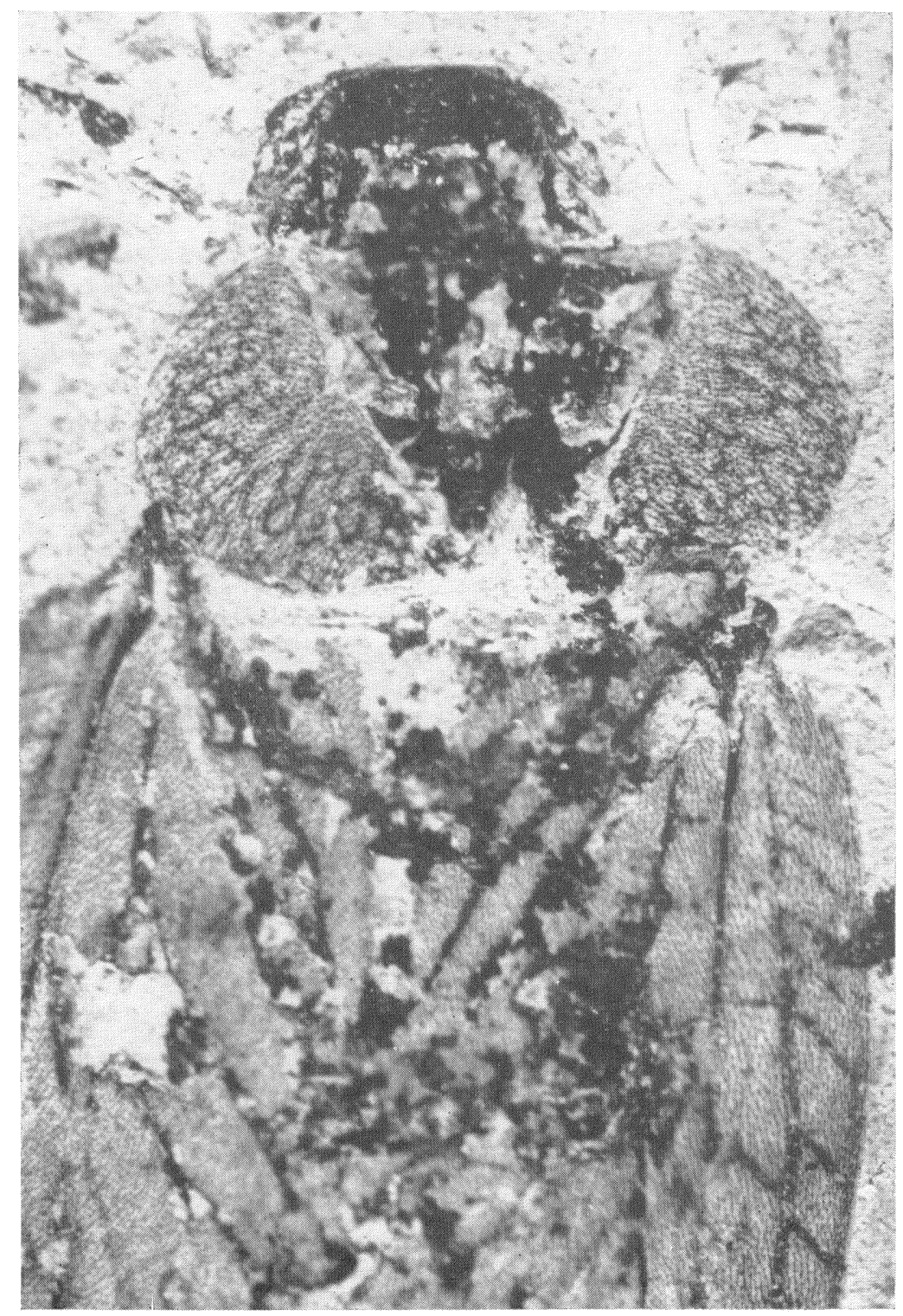

CARPENTER - Protorthoptera 
I consider the divergent vein as a modified cross vein, which in many cf the orthopteroids appears in diverse forms (e.g., Strephocladidae, figures $I$ and 2). It is my opinion, therefore, that the connections between $\mathrm{CuA}$ and $\mathrm{M}$ are of a diverse nature in the orthopteroids and that these connections have arisen independently many times.

Regarding Sharov's proposed classification of the Palaeozoic orthopteroids, I have previously ( 1954) adopted Zeuner's suggestion (also accepted by Sharov), that the Oedischiidae are true Orthoptera; Sharov has with good reason made a similar inclusion of a few related families (of which the Permelcanidae, figure 18 , is a representative). He then proposed restricting the Protorthoptera to the single family Sthenaropodidae, defining (1960, p. 295) the order as including those orthopteroids with "dorso-ventral flattening of the body, cursorial hind legs, lacking the two rows of spines on the hind margin of the tibia, by the small precostal area lacking the numerous veinlets and by the absence of an undifferentiated concave MA2." This definition I find much too narrow for an order; it might well fit a family - a small one - but certainly not an order. The remainder of the orthopteroids which I have previously included in the Protorthoptera, Sharov proposes to divide into the Protoblattodea and the Paraplecoptera. The former order he would restrict to those species having wide coriaceous fore wings, the absence of a clearly defined division of the media stem into two main branches, MA and MP, by large coxae and by general resemblance to Blattodea. In this case, Sharov's characterization seems to be much too broad and generalized. Certainly the coriaceous nature of the fore wings varies greatly within orders (e.g., Orthoptera); in some the fore wings are truly membranous but in others they are definite tegmina or even elytra. So far as the division of the media into MA and MP is concerned, I question that this is clearly divided in any of the orthopteroids; as noted above, there is no orthopteroid that has a convex, and therefore, definite, MA. The coxae are known in very few of the species that Sharov would place in the Protoblattodea and, once again, I cannot see this as an ordinal characteristic. The Paraplecoptera are distinguished by Sharov by the presence of membranous, clongated fore wings, by the clearly defined division of the median into MA and MP and by the general resemblance of the insects to the Plecoptera. On examining the genera which Sharov includes in the Paraplecoptera, as described and figured in the Osnovy (1962), I find many families (e.g., Spanioderidae, Probnidae, Strephocladidae, etc.) in which the fore wings are distinctly coriaceous and as rela- 
tively broad and oval as those of the previous order. The condition of MA and MP has already been commented upon.

I can see no justification in Sharov's account for the recognition of the Protorthoptera, Protoblattodea and Paraplecoptera as separate orders, and I propose to place all of these without subgrouping in the order Protorthoptera. Admittedly, the Protorthoptera as thus constituted would be almost certainly polyphyletic. But it seems to me that Sharov's classification would recognize two polyphyletic orders, (Protoblattodea and Paraplecoptera) with the order Protorthoptera itself so narrowly defined as to include only one family. In all probability, the Palaeozoic Orthopteroids were not evolving just in the direction of the living orders Blattodea, Plecoptera, and Orthoptera but, as a result of radial evolution, in many directions. Certainly this is what one would expect from the geological record of other groups of animals. The setting up of the three orders Protoblattodea, Paraplecoptera and Protorthoptera would seem to me to conceal what were almost certainly the real evolutionary lines of these insects. Hence, I prefer to group these orthopteroids into one large complex - the Protorthoptera - until we have enough evidence to indicate what the several lines of evolution have been. I do not believe that we have that now.

I am convinced that Sharov is correct in maintaining that the Lemmatophoridae are not sufficiently different from the Liomopteridae, etc., to justify separation in a distinct order, Protoperlaria. Certainly, as Sharov points out, both fore and hind wings of the Lemmatophoridae and related families can be distinguished from those of other Protorthoptera only with the greatest difficulty. I cannot agree wtih Sharov, however, in his claim that the paranotal lobes in the Lemmatophoridae were continuous and formed a pronotal shield as in Liomopteridae, instead of being independent lobes, as Tillyard and I had described them. Sharov states that his study of the published photographs in Tillyard's (1928) and Carpenter's (1935) papers shows that the lobes unite in front and behind. Although photographs are extremely useful in the study of fossils, they are no substitute for the actual specimens. Tillyard's drawing and mine were based on different specimens and were made several years apart. I have re-examined the material in both the Harvard and Yale collections since the publication of Sharov's paper and I cannot agree with the interpretation which he has made from the published photographs. Photographs of the thoracic region of two specimens of Lemmatophora typa Sellards are included here (plates 4 and 5). The first of these shows a specimen which is not quite in a symmetrical 


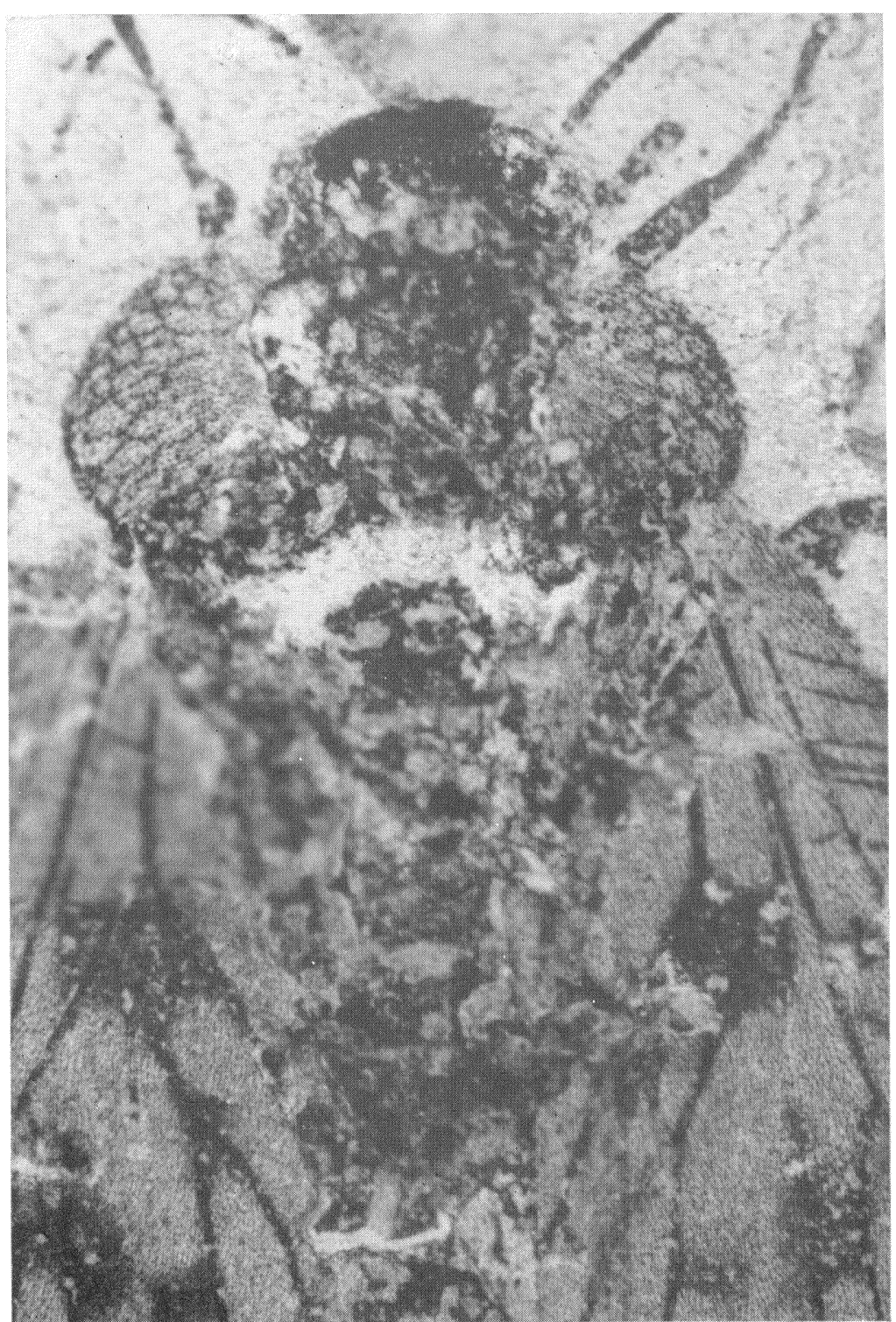

Carpenter - Protorthoptera 
position; it shows especially clearly the form of the individual lobes. 'The second specimen, which is the one originally figured by Tillyard, shows the thorax in a more symmetrical position. When Tillyard's original photograph was made, plant fragments and other organic debris covered much of the thorax, obscuring the form of the paranotal lobes posteriorly. Subsequently, as shown in the photograph on plate 5 , this debris was removed, presumably by Tillyard himself. The paranotal lobes are reddish-brown in color, like the true wings; the plant fragments and the debris are black, so that the two are more distinctive in the actual fossil than is apparent in a black-andwhite photograph. In any event, I do agree that these paranota are not sufficient to justify the separation of the Lemmatophoridae from the Protorthoptera.

In the preceding papers in this series, eight families of Protorthoptera were considered: Lemmatophoridae, Probnidae, Liomopteridae, Chelopteridae, Stereopteridae, Demopteridae, Phenopteridae and Protembiidae. In the present paper three additional families are covered, the Strephocladidae, Blattinopsidae, and Tococladidae, and the Stereopteridae are discussed further, in the light of new material.

\section{Family Strephocladidae Martynov}

Strephocladidae Martynov, 1938, p. 100.

Fore wing: coriaceous; precostal area absent; Sc well developed, extending to mid-wing or beyond, with several to many forked branches; Rs arising before mid-wing; RI extending well towards apex, with several oblique branches leading to margin beyond Sc; Rs very well developed, with several to many long branches, usually without forks except for the branches in the apical part of the wing; $M$ forked before origin of Rs, the anterior branch often touching Rs briefly or connected to it by a short, stout cross vein; $M$ with several long branches, usually simple, independent of $\mathrm{R}$ basally, often touching $\mathrm{CuA}$ briefly or connected to it by a stout cross vein or possibly by an anastomosed branch; $\mathrm{Cu}$ independent of $\mathrm{M}$ basally; $\mathrm{CuP}$ arising near base; $\mathrm{CuA}$ directed longitudinally, giving rise to several long branches, usually simple; branches of $\mathrm{Rs}, \mathrm{M}$ and $\mathrm{CuA}$ parallel and slightly sigmoidal; $\mathrm{CuP}$ usually nearly straight, except near its distal end; a distinct furrow posterior to $\mathrm{CuA}$, very close and parallel to it; IA close and parallel to $\mathrm{CuP}$; other anal veins irregular and

Explanation of Plate 5

Lemmatophora typa Sellards. Photograph of specimen No. 5115, Peabody Museum, Yale University. 
highly variable; cross veins numerous and regularly arranged over the areas of $\mathrm{Rs}, \mathrm{M}$ and $\mathrm{CuA}$; an irregular network in costal area and between $\mathrm{CuA}$ and $\mathrm{CuP}$ and the anal veins. Wing membrane with fine microtrichia between veins; prominent setae or other cuticular derivatives developed to variable degrees on most of the veins of wing, including many cross veins.

Hind wing unknown and body structure unknown, except for part of one leg.

This family has not been given any diagnosis previously, except by generic assignment. In the preceding account $I$ have attempted to bring together venational characteristics of the fore wing present in several Palaeozoic genera which are apparently closely related to Strephocladus and which I am placing in the family. However, the strephocladids will probably turn out to be an extensive group and its diagnosis will undoubtedly need modification as other genera become known.

Strephocladus was established in the Order Palaeodictyoptera by Scudder ( 1885 ) for a species (subtilis Kliver) which was collected in Upper Carboniferous strata of Saarbrücken and which had originally been placed by Kliver in the blattod genus Petroblattina. It has subsequently been placed in the order Protoblattoidea, Incertae Sedis, by Handlirsch (1908, I92I); in the order Protorthoptera, family Oedischiidae, by Waterlot ( I934) and Guthörl (1936); in a new order Strephocladodea, family (new) Strephocladidae, by Martynov (1938); in the order Paraplecoptera, family Strephocladidae by Sharov (I96I) ; and in the Protorthoptera, family Strephocladidae, by Kukalová (1965), who added another genus, Spargoptilon (L. Permian, Moravia), to the family. From my study of the type specimen of Strephocladus subtilis and of the several species from Elmo

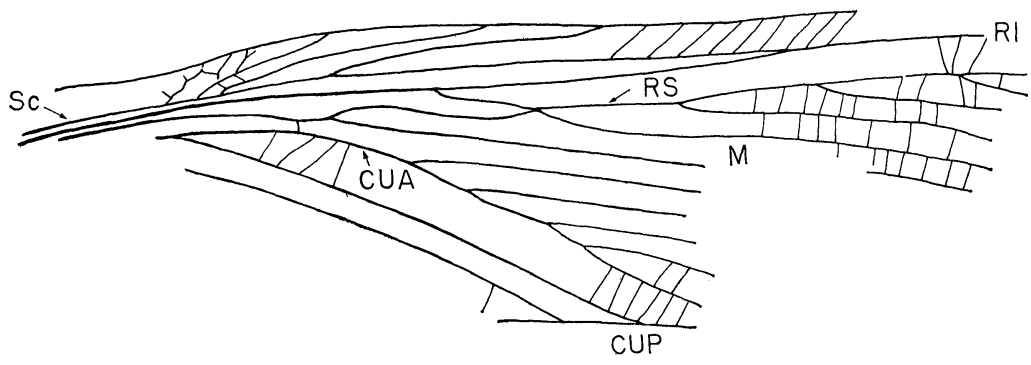

Text-figure 1. Strephocladus subtilis Kliver. Original drawing of fore wing, based on holctype, No. D/164, Bergingenieurschule, Saarbrücken. 
described below, I consider that the family Strephocladidae fits well within the order Protorthoptera and that Martynov's order Strephocladodea is synonymous with the order Protorthoptera. The relationships of the family Strephocladidae within the Protorthoptera are not so definite. The little-known Strephoneuridae Martynov, from the Lower Permian of URSS, are closest in venational details so far as they are known; but only when the hind wings and body structures have been found can these affinities be worked out satisfactorily.

The most significant features of the Strephocladidae are the presence of long, forked branches on Sc, and the long, parallel and nearly unbranched veins forming Rs, $M$, and $\mathrm{CuA}$. The identity of most of the main veins is clear; $\mathrm{R}_{\mathrm{I}}$ and $\mathrm{CuA}$ are strongly convex, and $\mathrm{Sc}$, $\mathrm{RI}$ and $\mathrm{CuP}$ are concave. The media does, as usual in the Protorthoptera, present a problem; it shows neither convex nor concave elements and is accordingly being designated here as M. In Strephocladus, Spargoptilon and the new genera herein described, $\mathrm{CuA}$ either arches anterior, touching $M$ briefly (Spargoptilon) or connects with $M$ by a stout cross vein; because of the convexity of all veins included, I agree entirely with Dr. Kukalovás interpretation that no branches of $\mathrm{M}$ are, in fact, involved in the $\mathrm{CuA}$ complex. The relationship between Rs and the anterior branches of $M$ seems to be similar; in some species (Spargoptilon) there is slight anastomosis, but in others the connection is by a cross vein. These variations almost certainly occur as individual fluctuations within species.

Apart from the general venational pattern, there are two features of the fore wings of strephocladids that deserve further comment. ( I). Setae on veins. Most orthopteroids possess fine microtrichia on the wing membrane and their presence on the wings of Protorthoptera is well known. The notable feature here is the presence of large setae on the veins, these being especially clear in Homocladus. These are, of course, represented in the main by setal bases, the setae themselves apparently being broken off in the rock matrix. These setae occur only on that half of the fossil (reverse) which has the impression of the dorsal surface of the wing; the ventral surface of the wing was apparently devoid of such setae. Setae have previously been found on the veins of a few Protorthoptera but they have not previously been noted as occurring so abundantly or regularly. Neither microtrichia nor setae are visible on the type specimen of Strephocladus subtilis but this is almost certainly the result of poor preservation of the fossil. (2) The costa, for a variable distance along the anterior margin, is actually sub-marginal for most of its length, there being a narrow but distinct, membranous border. This is a con- 
dition which occurs in many Orthoptera. Under low power magnification, this gives the impression that the costa is a much wider vein than it actually is. (See Plate 6).

Since the figures and descriptions of Strephocladus subtilis Kliver which have previously been published are not satisfactory, I include here ('Text-figure I) an original drawing of the type, which was placed at my disposal by Dr. G. Kneuper. The length of the preserved part of the wing is $20 \mathrm{~mm}$.; comparison with other Strephocladid wings indicates that the complete wing was about $30 \mathrm{~mm}$. There are three distinctive features of the wing that separate Strephocladus from other genera now known in the family: the presence of short, oblique veins from $\mathrm{Sc}$ to the costal margin, the definite termination of $\mathrm{Sc}$ on $\mathrm{RI}_{\mathrm{I}}$; and the pectinate origin of the branches of $\mathrm{CuA}$. As can be seen in the figure, the front branch of $M$ is in brief contact with $\mathrm{R} ; \mathrm{CuA}$ is joined by a short cross vein to $\mathrm{M}$. It should be noted that the stem of $M$ is not convex, and that the vein designated $\mathrm{CuA}$ is entirely convex. The shallow furrow, directly posterior to $\mathrm{CuP}$, can clearly be seen.

The following are the strephocladids in the Elmo limestone:

\section{Genus Homocladus, new genus}

Fore wing: costal margin with a distinctly arched border at about the level of the origin of $\mathrm{Rs}$; Sc with numerous long, branched veinlets, directed longitudinally and terminating on costal margin; Rs arising at about one-third the wing-length from the base, giving rise to numerous, long branches, all simple except near the wing apex; $M$ forked just before the origin of Rs, forming several long, simple branches; fork of $\mathrm{CuA}$ at least slightly basal of the first fork of $M$; $\mathrm{CuP}$ at its distal end extending parallel and close to the wing margin, this marginal vein being continuous basally by extensions of the

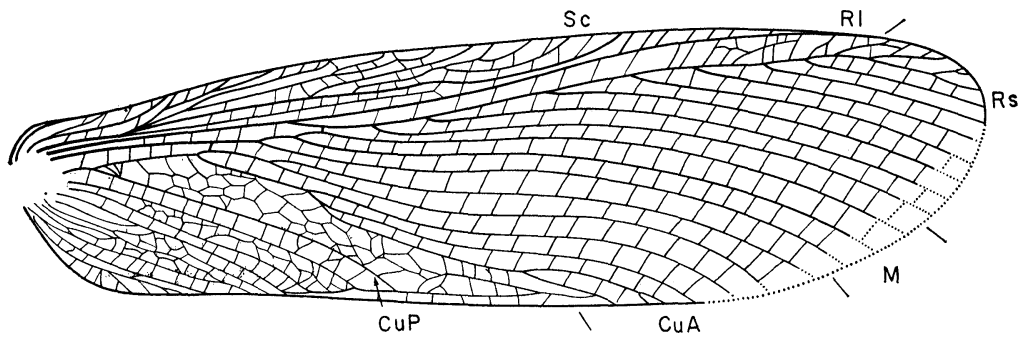

Text-figure 2. Homocladus grandis, n. sp. Drawing of fore wing (holotype). 
anal veins; branches of $\mathrm{CuA}$ arising dichotomously, more curved than those of Rs and $M$; apex of wing much nearer the anterior wing margin than the posterior. Area between $\mathrm{CuA}$ and $\mathrm{CuP}$ with a coarse reticulation of cross veins. Hind wing unknown.

Type-species: Homocladus grandis, n. sp.

This genus differs from Strephocladus in lacking the straight, oblique branches to the costa, and in having the branches of $\mathrm{CuA}$ arising dichotomously, instead of pectinately; it differs from $S$ pargopitilon by its more slender wing shape, the pectinate, instead of dichotomous, branching of Rs, and in the position of the distally extended part of CuP.

Homocladus grandis, n. sp.

Text-figures 2, 3, 4 and Plate 6

Length of fore wing (holotype) : $43 \mathrm{~mm}$.; width, I I mm. Costal area with only a slight broadening before mid-wing; several rows of cells between $\mathrm{CuA}$ and $\mathrm{CuP}$; wing without markings; setae

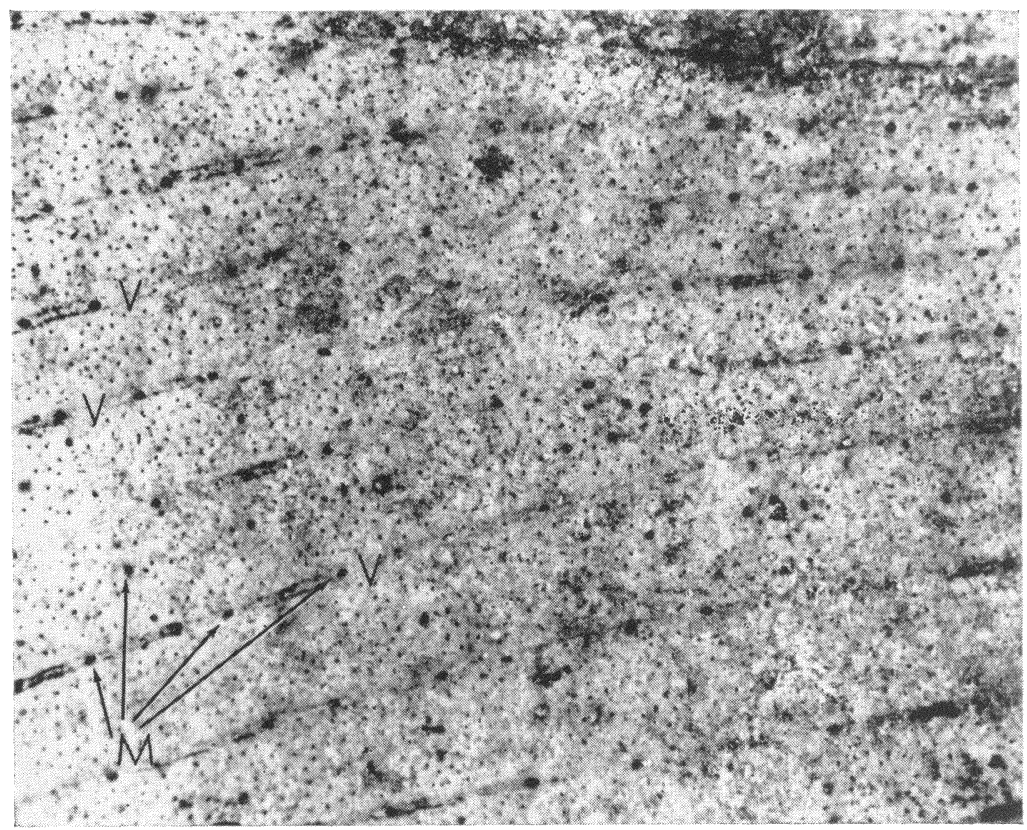

Text-figure 3. Homocladus grandis, n. sp. Photograph of wing surface of holotype, showing veins $(V)$ and setal bases $(M)$ on veins and membrane; and microtrichia on membrane. 
numerous and well developed on main veins and some cross veins. The venational details of the holotype are shown in figure 2.

Holotype: No. 5874ab, Museum of Comparative Zoology; collected by F. M. Carpenter, in the lower layer of the Elmo limestone in 1927 . The specimen consists of a very nearly complete fore wing, lacking only the distal wing margin. A second specimen (No. MCZ $5875 \mathrm{ab}$ ), with the same collecting data, consists of the proximal twothirds of a fore wing; a drawing is included here to show the apparent fluctuation in the venation. Also on this piece of rock, only 2 or $3 \mathrm{~mm}$. from the wing, is part of a femur and tibia of a leg; the proximity and size of this leg indicate that it is from the same insect as the wing. The tibia is armed with two rows of heavy spines and the femur bears a few smaller ones.

\section{Homocladus ornatus, n. sp.}

Text-figure 5

Fore wing: length, as preserved, $20 \mathrm{~mm}$.; width, $7 \mathrm{~mm}$.; estimated complete wing length, $30 \mathrm{~mm}$. Costal area with a more prominent broadening than in grandis; area between $\mathrm{CuA}$ and $\mathrm{CuP}$ with fewer cells; wing at least four transverse bands. Venational details are shown in figure 5 .

Holotype: No. 15584, Peabody Museum, Yale University; collected in Elmo limestone by C. O. Dunbar, I92I.

This species differs from grandis mainly by the wing markings and smaller size.

\section{Genus Paracladus, new genus}

Fore wing: costal margin almost smoothly curved; Sc with several oblique veinlets, mostly branched, but generally much less developed than in Homocladus; Sc apparently terminating either on

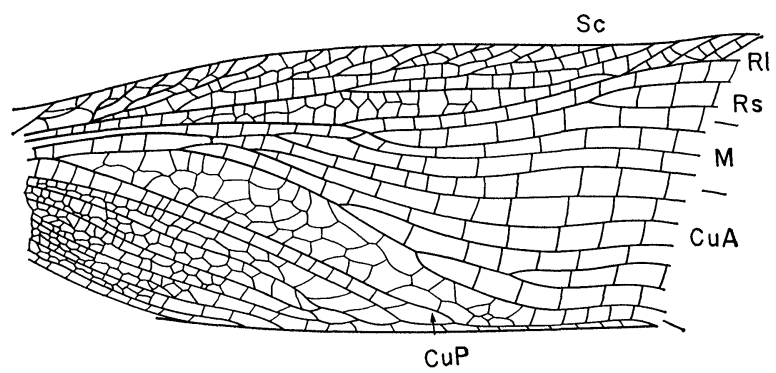

Text-figure 4. Homocladus grandis, n. sp. Drawing of fore wing (paratype no. $5875 \mathrm{ab})$. 
margin or RI; origin of Rs at or slightly beyond mid-wing, its branches arising dichotomously; $\mathrm{CuP}$ only very slightly curved distally, without the terminal extension as in Homocladus. Microtrichia on wing membrane more numerous than in Homocladus; setae on veins apparently less developed and less numerous.

Type-species: Paracladus retardatus, n. sp.

This genus, though clearly related to Homocladus, differs by the late origin of Rs, and especially by the absence of the marginal extension of CuP; in the latter respect, it resembles Strephocladus.

\section{Paracladus retardatus, n. sp. Text-figure 6}

Length of fore wing, as preserved, $20 \mathrm{~mm}$.; width, $7 \mathrm{~mm}$.; estimated complete wing length, $30 \mathrm{~mm}$. Subcosta space distinct and rather wide, with a few cross veins; relatively few cells between $\mathrm{CuA}$ and $\mathrm{CuP}$; IA connected to $\mathrm{CuP}$ distally by a strong, longitudinal cross vein. Wing markings absent. Venational details are shown in figure 6.

Holotype: No. 5877ab, Museum of Comparative Zoology; collected in the lower layer of Elmo limestone in 1932 by F. M. Carpenter.

\section{Family Blattinopsidae Bolton}

Blattinopsidae Bolton, 1925, p. 23.

Oryctoblattinidae Handlirsch, 1906, p. 705 (Oryctoblattina is a junior objective synonym of Blattinopsis).

Fore wing: membrane apparently thin, at most weakly coriaceous; wing generally oval but often very short; Sc extending at least to mid-wing, often considerably beyond; area between Sc and RI at least

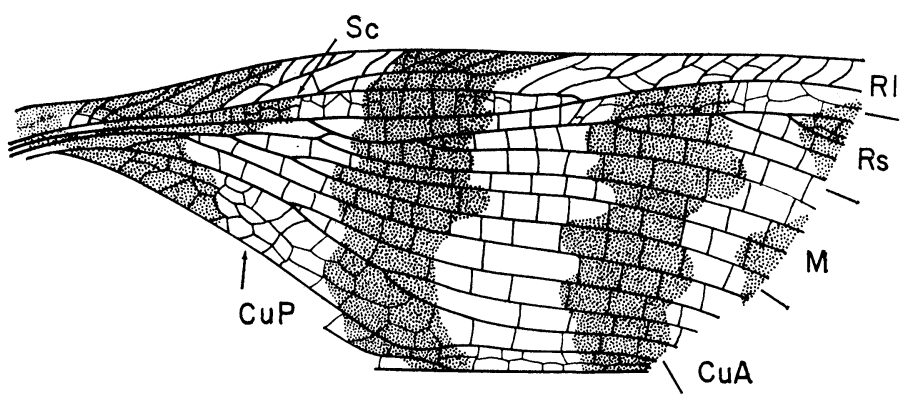

Text-figure 5. Homocladus ornatus, n. sp. Drawing of fore wing (holotype). 
as wide as the costal space; $\mathrm{R}_{\mathrm{I}}$ usually slightly sigmoidal; Rs usually arising at about one-quarter of the wing length from $\mathrm{R}_{\mathrm{I}}$ and giving iise to several branches either dichotomously or pectinately; $M$ apparently independent of $\mathrm{R}$ at the base, although very close to it in some species; $M$ almost always with at least two terminal branches; $\mathrm{CuAI}$ apparently anastomosed with the stem of $\mathrm{M}$ for a considerable distance, diverging posteriorly from it just before the level of the origin of $\mathrm{Rs}$, then coalescing for a variable distance with $\mathrm{CuA}_{2}$; $\mathrm{CuP}$ arising from the stem of $\mathrm{Cu}$ near the base of the wing and continuing as a nearly straight, strongly concave vein; the posterior margin of the wing is usually strongly indented at the termination of $\mathrm{CuP}$; IA usually very close to $\mathrm{CuP}$ and in some species apparently anastomosed with it; usually at least two other distinct anal veins present; cross veins highly variable in form, usually numerous and often forming a reticulation over the central and posterior portions of the wing; a curved transverse line, starting from $\mathrm{R}_{\mathrm{I}}$ at about the level of the end of $\mathrm{Sc}$ and terminating on $\mathrm{CuA}$ at about the level of the first definite fork of $\mathrm{CuA}$, is visible on the wings of most members of the family.

The hind wings and body of the blattinopsids are almost entirely unknown; a short, stout ovipositor apparently existed in some species (Kukalová, 1959). A fragmentary wing, probably a hind wing, is the basis of the description of Blattinopsis elegans Handlirsch ( I906, p. I60), from the Upper Carboniferous of Germany; however, since this wing is not associated with a fore wing and since the venation of the remigium is distinctly different from that of the fore wing, there is no real basis for considering this to be a member of Blattinopsis. Laurentiaux (1950, p. 66) has established Blattinopsis incerta (Upper Carboniferous of France) for a specimen consisting of

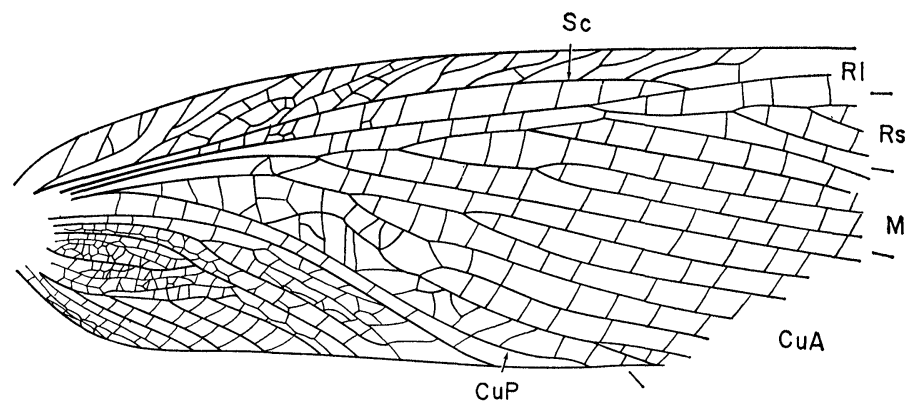

Text-figure 6. Paracladus retardatus, n. sp. Drawing of fore wing (holotype). 
a fore wing and part of a hind; however, venational details of the fore wing, such as the proximity of $S_{c}$ to $\mathrm{R}_{\mathrm{I}}$, eliminate this species from Blattinopsis; it is herein assigned to the genus Stephanopsis Kukalová, which was erected as a subgenus of Blattinopsis in 1958 (p. 131), with incerta as the type species of the subgenus. This is the only species, apart from the very dubious elegans Handlirsch, previously mentioned, which can be assigned at the present time to Stephanopsis. It is highly doubtful, in my opinion, that Stephanopsis actually belongs to the Blattinopsidae.

The venation of the fore wings of the blattinopsids presents some difficulties, at least with respect to homologies of $\mathrm{M}$ and $\mathrm{CuA}$. In all members of the family which have been described, the basal portion of $M$ is strongly convex and the remainder concave or at least neutral. The change in the topography of this veins occurs as a strongly convex branch diverges obliquely, fusing with what is obviously part of the anterior cubitus, as shown in figure 7 and in the numerous illustrations of blattinopsids given by Kukalová ( 1959, 1965). The venation of the blattinopsids, in this respect, is different from that of the carcurgids (i.e., Heterologus) and the oedischiids in having no concave vein between $\mathrm{CuP}$ and $\mathrm{CuA}$. It seems most likely to me that $\mathrm{CuAI}$ is coalesced with $\mathrm{M}$ basally and that it then diverges off as the oblique vein and anastomoses with $\mathrm{CuA}$. Sharov (1962) is of the opinion that MP is the oblique vein that coalesces with $\mathrm{CuA}$. This interpretation, however, does not explain the strong convexity of the base of $M$, the convexity of the oblique vein itself, or the change in the topography of the rest of $M$ beyond the divergence of the oblique vein.

In some genera of blattinopsids (i.e., Glaphyrophlebia) distinct grooves extend longitudinally between the branches of Rs and M. They have been represented in some figures (Handlirsch, 1906) as actual veins but examination of these wings under high magnification and optimum illumination fails to show any sign of cuticular lines along the grooves. Actually, these structures seem to be shallow depressions in the membrane bordered by low ridges of membrane; similar surface features are found in the wings of various genera of orthopteroid insects, including the Blattodea.

The most notable structure in the blattinopsid fore wings is a curved line which runs transversely from $\mathrm{R}_{\mathrm{I}}$ at about the middle of the wing to $\mathrm{CuA}$ or even slightly beyond. Kukalová (1959) has pointed out that this resembles the line in the fore wings of some Recent cockroaches of the family Polyphagidae, in which it is apparently formed by spreading and folding of the wings. Others have 
noted the similarity of this line to the transverse mark that occurs in the fore wings of some Homoptera, and Haupt (1941, p. 88) has actually established a new order, Protofulgorida, for the Blattinopsidae, which he regards as closely related and ancestral to the Homoptera. All available evidence, however, indicates that the blattinopsids are undoubtedly orthopteroid. For example, the details of venation are surely like those in other Protorthoptera and the anal area is clearly orthopteroid, not homopterous.

Previous accounts of the blattinopsids (Bolton, 1925, Kukalová, 1959) have noted the fragmentary nature of all specimens of fore wings. So far as I am aware only one species, Glaphyrophlebia speciosa (Sellards), is known from a complete wing. In most specimens, either the apical region or the anal area has been broken away. This is true even of such relatively large species as Blattinopsis kukalovae, described below, and it is in marked contrast to the frequency of occurrence of undamaged wings of such small and delicate insects as the Homoptera and Psocoptera in the Elmo limestone. This circumstance seems to indicate that the fore wings of the blattinopsids were unusually thin and delicate.

\section{Genus Blattinopsis Giebel}

Blattinopsis Giebel, 1867, Zeitschr. Ges. Naturw. $30: 417$; Kukalová, 1959, Rozpravy. Ceskos. Acad. Ved. 69:(1):5.

Oryctoblattina Scudder, 1895, Bull. U.S. Geol. Surv. 124:133 (jr. obj. syn.).

Fore wing: costal area and area between $\mathrm{Sc}$ and $\mathrm{R} I$ with numerous oblique veinlets, very close together and often branched; area between branches of $\mathrm{Rs}, \mathrm{M}$ and $\mathrm{Cu}$ with similar cross veins, those in the

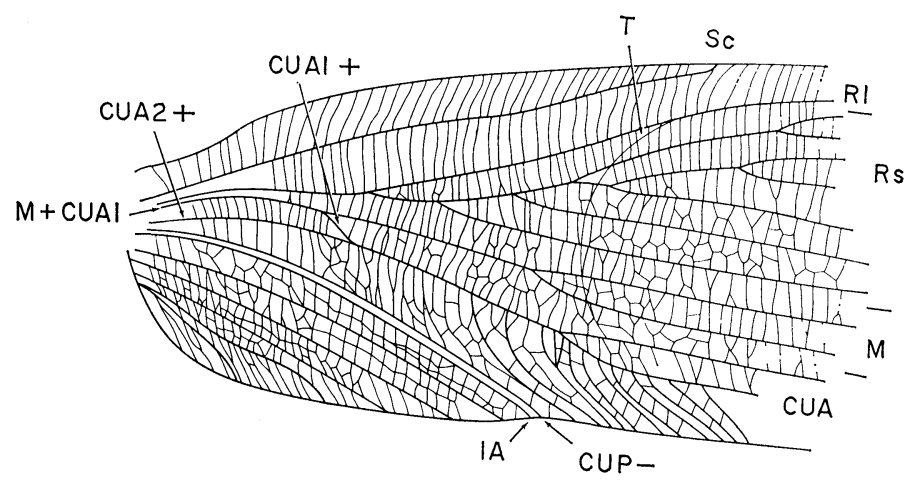

Text-figure 7. Blattinopsis kukalovae, n. sp. Drawing of fore wing (holotype). $\mathrm{M}+\mathrm{CUA1}$ is the convex base of these coalesced veins; $\mathrm{T}$ is the transverse line. 


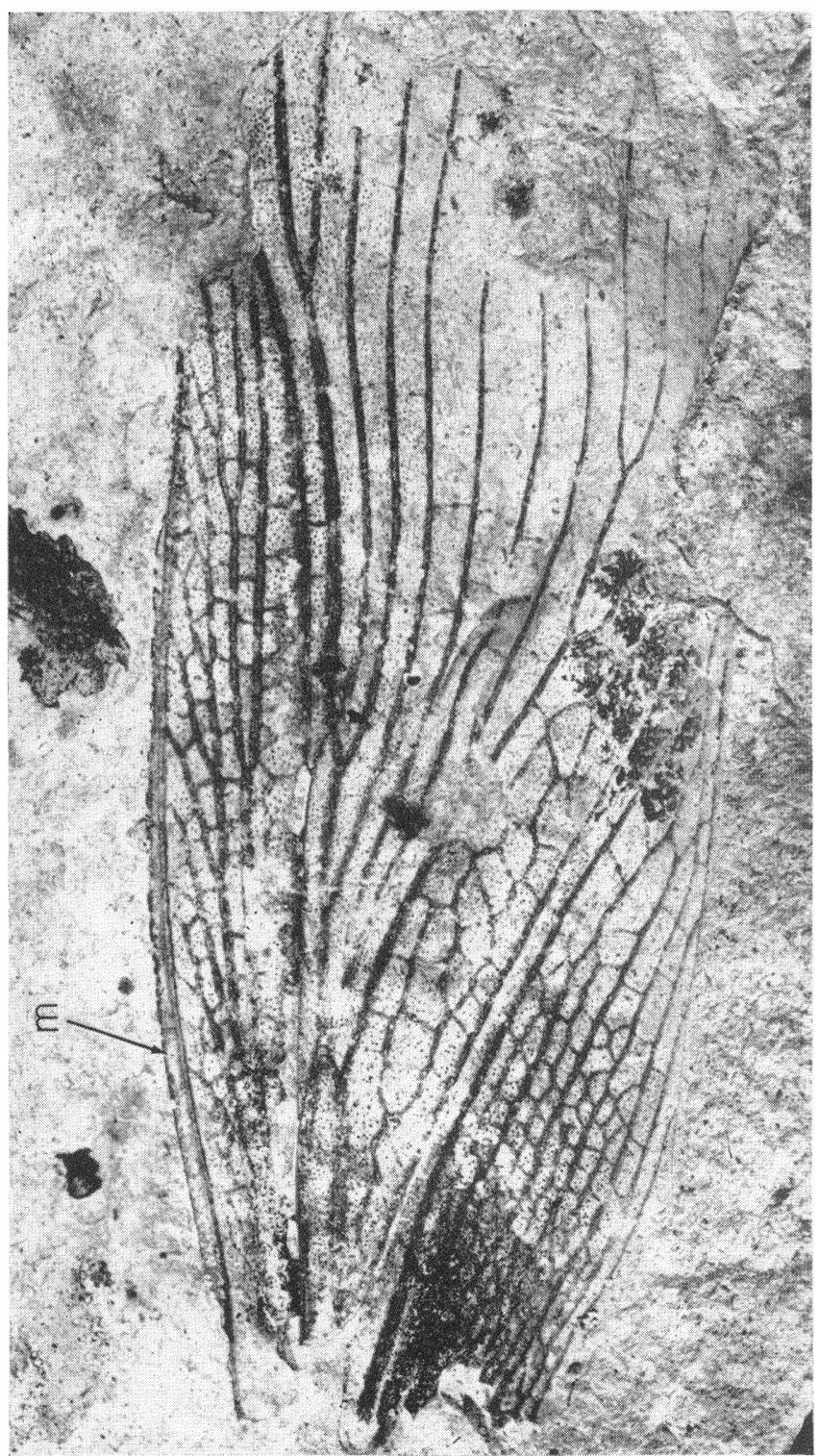

.

일

岁

ฮั

进山

ह्ञें

ن :

嵓苟

घ 밈

号

$\Sigma$

กิ ธี

in $\frac{0}{0}$

$\circ \cdot \frac{m}{b}$

용

จำ

㟧

政

पू

도웛

क

․

영

के

म 픔

it

:

เิ

.

క

:

트

논

ह્ 
distal part forming a fine reticulation; area between $\mathrm{CuA}$ and $\mathrm{CuP}$ with numerous oblique, parallel branches, mostly slanted towards the posterior margin and parallel to $\mathrm{CuP}$; anal area with numerous cross veins forming a reticulation.

Generic limits of Blattinopsis are very difficult to make because of the obvious variation in the venation within species. I consider it advisable to treat this genus broadly, as was done by Kukalová. 'The type-species, Blattina reticulata Giebel, is not so well known as several others, but there is no question about its basic venation. The genus has been recorded from Upper Carboniferous and Lower Permian strata of both Europe and North America. The probable generic synonomy has been discussed by Kukalová (1965).

\section{Blattinopsis kukalovae, n. sp. Text-figure 7}

Fore wing: incompletely known; estimated length, $22 \mathrm{~mm}$.; hølotype (basal half of wing), $12 \mathrm{~mm}$; width $7 \mathrm{~mm}$. Costal margin nearly straight, not conspicuously arched; costal area narrowed at wing base; venation typical of the genus; Rs arising from a single stem; $M$ (in holotype and paratypes) with a deep fork; cross veins in costal area and between $R_{I}$ and $S c$, and $R_{I}$ and Rs very close together and parallel, almost without cellules; reticulation between branches of $\mathrm{Rs}, \mathrm{M}$ and $\mathrm{CuA}$.

Holotype: No. 630rab, Museum of Comparative Zoology; consisting of basal half of a wing; collected by F. M. Carpenter in the upper layer of the Elmo limestone.

Paratype: No. 6302ab, Museum of Comparative Zoology; consisting of a more distal portion of the wing, lacking the apex; paratype No. I5582ab, Peabody Museum, Yale University; collected by C. O. Dunbar; middle portion of the wing, not so well preserved. A third specimen, No. I5633b, Peabody Museum, is a small fragment which probably belongs to this species.

This species has the wing form and size of the type-species of the genus, but it lacks the reticulation in the area between $\mathrm{RI}_{\mathrm{I}}$ and $\mathrm{Sc}$, and the subcosta is considerably shorter than in reticulata. It differs from most of the species described by Kukalová from the Permian of Czechoslovakia in having ( $\mathrm{x}$ ) the costal margin smoothly curved, (2) less reticulation of the cross veins and (3) a much less conspicuous lobation of the anal area.

The species is named for Dr. Jarmila Kukalová of Charles University in Prague, in recognition of her achievements in both collecting and studying the Permian insects of Moravia. 


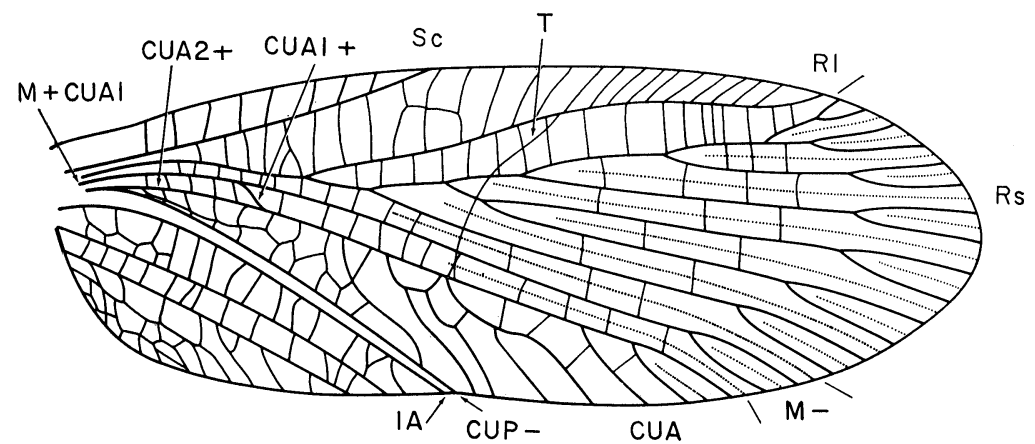

Text-figure 8. Glaphyrophlebia speciosa (Sellards). Drawing of fore wing, based on neotype.

\section{Genus Glaphyrophlebia Handlirsch}

Glaphyrophlebia Handlirsch, 1906, Proc. U.S.N.M. 29:707.

Sindon Sellards, 1909, Amer. Journ. Sci., 27:154.

Pursa Sellards, 1909, ibid. 27:153.

Fore wing: membranous or weakly tegminous; Sc terminating at or slightly beyond mid-wing; costal and subcostal areas with few cross veins; Rs arising at or slightly before mid-wing, with numerous branches, most of them forked distally; $\mathrm{M}$ and $\mathrm{Cu}$ as in Blattinopsis, but usually with fewer branches leading from $\mathrm{CuA}$ to the hind margin distally; areas of Rs and $M$ with a few, widely scattered distinct cross veins, not forming a reticulation; curved line across middle of wing, much as in Blattinopsis; space between branches of Rs and $M$ with a prominent groove or grooves parallel to the veins. Hind wing unknown.

Type-species: Glaphyrophlebia pusilla Handlirsch, from Grove County, Pennsylvania, Illinois; Upper Carboniferous. The typespecimen of pusilla consisted of the distal two-thirds or half of a fore wing ${ }^{6}$ although it is well preserved, Handlirsch did not distinguish between the actual forks of the branches of $\mathrm{Rs}$ and the grooves in the intervening membranes. Almost certainly the veins had two distal forks, as in the other species now known in the genus.

\footnotetext{
${ }^{6}$ The type and only known specimen of pusilla was contained in the Daniels Collection at the time of Handlirsch's description. This collection was supposedly turned over to the U.S. National Museum (Handlirsch, 1906, p. 662) but apparently it was not; none of the specimens originally in the Daniels Collection are in the National Museum.
} 
This genus is undoubtedly close to Blattinopsis but differs from it by having ( $I$ ) distinctly few cross veins over the wing in general and especially in the distal portion and (2) clearly defined grooves in the wing membrane between the branches of Rs and M. Sindon Sellards and Pursa Sellards seem to me to be inseparable from Glaphyrophlebia; as shown below, the type-species of both of these genera possess the venational characteristics of Handlirsch's genus. Glaphyrophlebia is represented by one species (clava Kukalová) from the Lower Permian of Moravia and two species (uralensis Martynov and rossicum Martynov) from the Permian of USSR, both originally described in Sindon.

\section{Glaphyrophlebia speciosa (Sellards) \\ Text-figure 8}

Sindon speciosa Sellards, 1909, Amer. Journ. Sci., $23: 154$, fig. 1.

Fore wing: length, $8 \mathrm{~mm}$., width, $3.8 \mathrm{~mm}$. (neotype). Sc terminating at mid-wing; RI strongly sigmoidal; Rs with seven main branches, each forked distally; $M$ (in type, probably variable) forked only near wing margin; oblique part of $\mathrm{CuA}$ slightly basal to the origin of $\mathrm{Rs}$; $\mathrm{CuA}$ with only about six branches leading to the hind margin; costal veinlets unbranched (in type), separated by spaces about equal to their length; cross veins in the area of the subcosta and $R_{I}$ with similar spacing; veinlets from $R_{I}$ to the costal margin beyond the end of $\mathrm{Sc}$ somewhat more numerous and closer together; cross veins in the area of $\mathrm{Rs}, \mathrm{M}$ and $\mathrm{CuA}$ widely spaced; no reticulation between $\mathrm{CuA}$ and $\mathrm{CuP}$, although two rows of cells occur in that area basally; anal area without a reticulation.

The holotype specimen, No. 85 in the Sellards collection, was studied by me in 1927, at Austin, Texas. Since this fossil has subsequently been lost, I designate as the neotype specimen No. 6303, in the Museum of Comparative Zoology. This was collected at Elmo, by F. M. Carpenter in 1927 ; it consists of a complete and well preserved fore wing. Sellards figure of the original type was slightly in error in showing Sc too long and in showing too many branches from $\mathrm{CuA}$ to the wing margin. The neotype is very close to the original type except that in the latter the fork of $M$ was much deeper. As pointed out by Kukalová (1965), the branching of $M$ is subject to much fluctuation within the species of Blattinopsidae.

'The venational details of this species are shown in text-figure 8 . So far as I am aware, this is the only species of the Blattinopsidae known from a complete wing. 


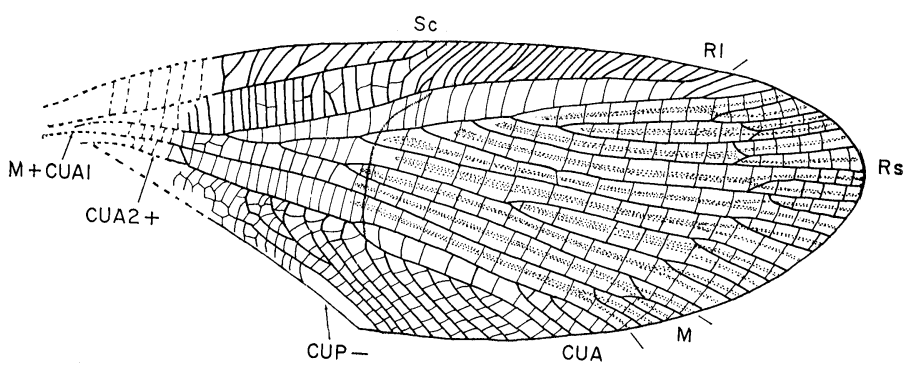

Text-figure 9. Glaphyrophlebia ovata (Sellards). Drawing based on neotype.

\section{Glaphyrophlebia ovata (Sellards) \\ Text-figure 9}

Pursa owata Sellards, 1909, Amer. Journ. Sci., 27:156, fis. 4.

Fore wing: length $8 \mathrm{~mm}$; width, $3.5 \mathrm{~mm}$. (neotype). Sc terminating at mid-wing; $\mathrm{R}$ I slightly sigmoidal; Rs with 9 branches, each forked distaily (neotype) ; $M$ forked only at wing margin (neotype); costal veinlets and those between $\mathrm{R}_{\mathrm{I}}$ and $\mathrm{Sc}$ much closer together than in speciosa; cross veins between $\mathrm{RI}$ and anterior margin numerous and close together; cross veins between $\mathrm{R}_{\mathrm{I}}$ and $\mathrm{Rs}$ and between branches of $\mathrm{Rs}$ much as in speciosa; $\mathrm{CuA}$ with about $\mathrm{I} 3$ branches leading to hind margin, close together and parallel; area between $\mathrm{CuA}$ and $\mathrm{CuP}$ with a reticulation basally.

The holotype specimen, No. I I 26 in the Sellards collection was studied by me in 1927 ; since that has subsequently been lost, I designate as the neotype specimen No. 4965ab, Museum of Comparative Zoology; this was collected by F. M. Carpenter, at Elmo, in I927. It consists of a very well preserved fore wing, lacking the anal area. The species is similar to speciosa but has the veinlets in the costal and subcostal areas much more numerous; it also has more branches of $\mathrm{Rs}$ and of $\mathrm{CuA}$. The grooves of the membrane between the branches of $\mathrm{Rs}$ and $\mathrm{M}$ are more complicated than in speciosa, each one apparently being composed of 2 or 3 fine grooves.

Sellards figure of ovata, based on a poorly preserved wing, confused the branches of Rs with grooves between them and also incorrectly represented the structure of $M$. This species has the relatively small number of cross veins and lack of reticulation characteristic of Glyphrophlebia but has more cross veins and veinlets from $\mathrm{CuA}$ to the hind margin than speciosa does; in these respects it suggests the condition in Blatinopsis more than the latter. 


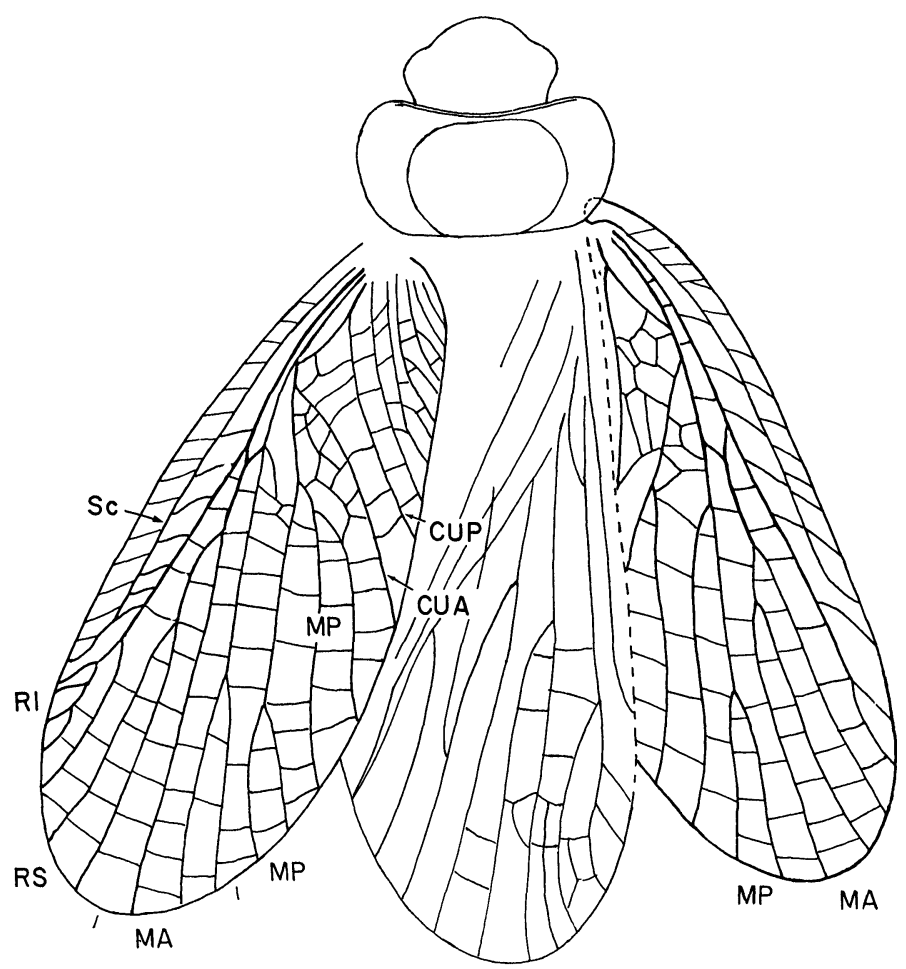

Text-figure 10. Stereopterum breve, n. sp. Drawing based on holotype.

Family Stereopteridae Carpenter

Stereopteridae Carpenter, 1950, p. 201.

This family was established on a single species, Stereopterum rotundum Carpenter, from the Elmo limestone. Several additional specimens of this insect have subsequently been found as well as representatives of two other species, described below. In one of the latter ( $S$. breve, n. sp.) the prothorax is seen to be broad, with the pronotum extended laterally, but truncate anteriorly and posteriorly. Nothing further is known of the body structure in this family.

The stereopterids were probably related to the Euryptilontidae, known from the Lower Permian of the USSR. The prothorax seems to be quite differently formed in these two groups and until the hind wings are known, it seems advisable to recognize the families as distinct. 
Stereopterum rotundum Carpenter

Text-figures I I, I2

Stereopterum rotundum Carpenter, 1950, Proc. Amer. Acad. Arts Sci. 78 : 202.

Six additional specimens have been collected in the Elmo limestone since I950, these bearing numbers 4959, 5253, 5254, 5258, 5259,5260 ; all were collected in the lower layer of the limestone (F.M.C.). The species has not yet been recorded from the upper layer. A survey of all of these fossils shows a greater variation in the venational pattern of the fore wing than has previously been realized. The subcosta and $\mathrm{R}_{\mathrm{I}}$ remain fairly constant. $\mathrm{Rs}_{\mathrm{s}}$ in several specimens $(4959,5880,5885)$ has a deep fork; in another $(5887)$ it has three branches instead of 2 and in a third (5879) it is unbranched. In the type specimen (4922) it has a shallow, distal fork. In a few specimens $(5886,5879,5885)$ MAI is anastomosed for a short distance with Rs; in others, as well as the type, it is free from Rs. The weak condition of the basal part of $\mathrm{CuA2}$, as seen in the type, is apparently unusual ; in most specimens (e.g., 5887, 5879 ) it arises distinctly from the stem of $\mathrm{CuA}$; in one specimen (5886) it arises from $\mathrm{CuA}+\mathrm{M}$, i.e., before the separation of $\mathrm{CuA}$ from M. The pattern of cross veins is variable but essentially as shown in the type; beyond the end of $\mathrm{Sc}$ the oblique veinlets from $\mathrm{R}_{\mathrm{I}}$ to the margin are somewhat closer together than elsewhere; this seems to be consistent in all specimens. The distinctive cluster of hairs on MA and MP near the middle of the wing can be seen in several specimens in addition to the type (e.g., 5879); few smaller setae are visible on some other veins but they do not form a definite patch.

All of the fossils which show the base of the wing have a distinct lobe which resembles a heavily sclerotized fold of the costal area extending backwards of the base of $\mathrm{Sc}$ and $\mathrm{R}$ (see text-figure II). Having noted this in several specimens, I attempted to chip away the very base of the type specimen, which turns out to have the lobe present also. This lobe was probably concerned with the fitting of the tegmen against the pronotum when the wings were in the resting position; a variety of sclerotized structures, which occur at the wing bases in many living orthopteroids, seem to have a similar function.

Drawings of two specimens are included here (text-figures IO and I I ) to show the extreme variation in some of the features mentioned. It should be noted that in one of the specimens (5886) there is no 
basal connection between $\mathrm{CuP}$ and $\mathrm{CuA}$, although the latter produces both $\mathrm{CuA}_{1}$ and $\mathrm{CuA}_{2}$ directly from $M$. In the other specimen (4958) both $\mathrm{CuAI}$ and $\mathrm{CuA}_{2}$ arise from MP, not from the stem of $\mathrm{M}$.
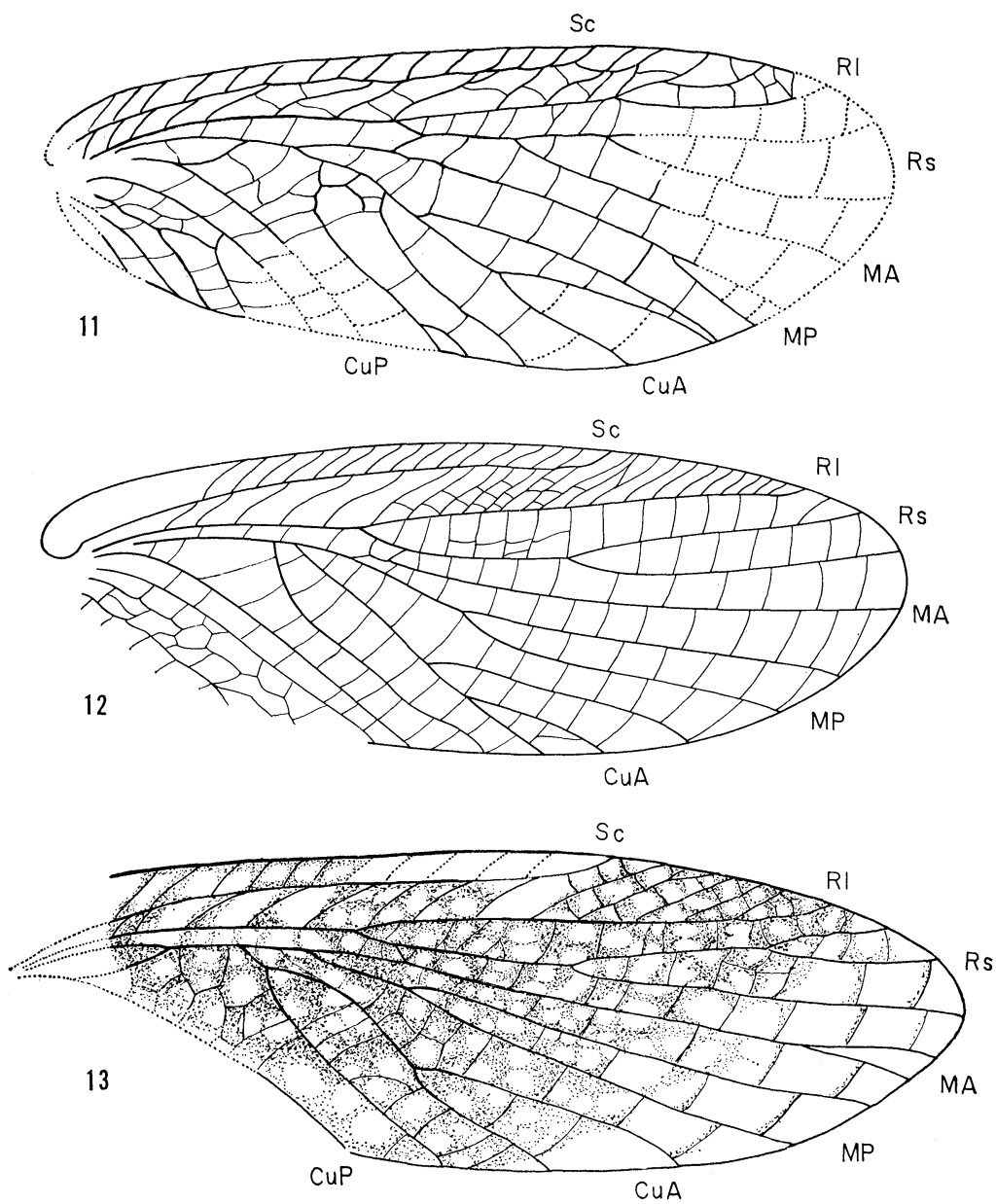

Text-figure 11. Stercopterum rotundum Carpenter. Drawing of specimen no. 5886, M. C. $Z$.

Text-figure 12. Stereopterum rotundum Carpenter. Drawing based on specimen no. 4958, M. C. $Z$.

Text-figure 13. Stereopterum maculosum, n. sp. Drawing based on holotype. 


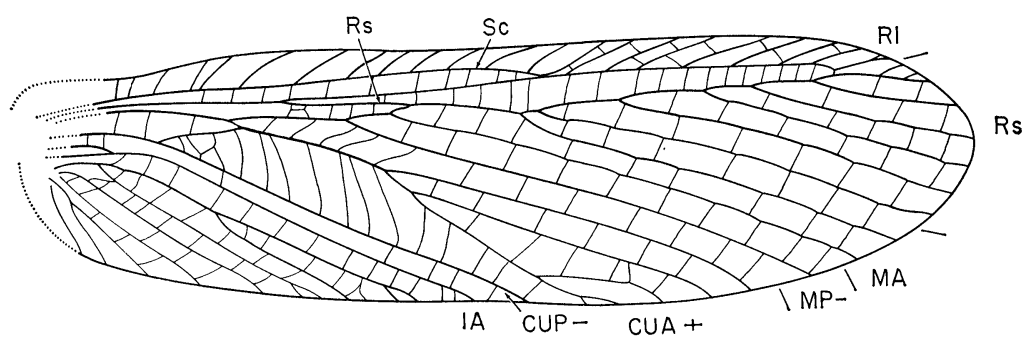

Text-figure 14. Tococladus rallus, n. sp. Drawing of fore wing (holotype).

\section{Stereopterum maculosum, n. sp.}

Text-figure 13

Fore wing: length, $8.5 \mathrm{~mm}$., width, $3.2 \mathrm{~mm}$. (holotype); more slender than that of rotundum; Rs usually with some coalescence between Rs and MAI ; CuA or CuAi anastomosed with stem of M; cross veins in area between $\mathrm{CuA}$ and $\mathrm{CuP}$ forming a very coarse network; wing distinctly coriaceous, with numerous irregular maculations, preserved as reddish-brown spots.

Holotype: No. 15653, Peabody Museum of Natural History, Yale University; collected in the Elmo limestone by C. O. Dunbar. This consists of a nearly complete wing, lacking the anal area and portions of the wing base and anterior margin.

Paratypes: No. 5257, Museum of Comparative Zoology ; collected in the lower layer of the Elmo limestone by F. M. Carpenter; this consists of a nearly complete fore wing, lacking only the basal part; a plant fragment rests near mid-wing, obscuring the veins in a small area. No. 4958, Museum of Comparative Zoology, collected in Elmo limestone, lower layer, by F. M. Carpenter. This consists of a nearly complete fore wing lacking the apical quarter and parts of the hind margin and anal areas. This is the only specimen of maculosum which shows the basal part of the wings; the peculiar lobe at the base of the costal area is not present, although there are several prominent spines along the costal margin basally, much as in rotundum.

Apart from its shape, maculations, and more pronounced coriaceous texture, this wing differs from that of rotundum by the more widely spaced cross veins and the coarser network between $\mathrm{CuA}$ and $\mathrm{CuP}$.

\section{Stereopterum breve, n. sp. Text-figure ro}

Fore wing: length, $7.5 \mathrm{~mm}$.; width, $3.5 \mathrm{~mm}$.; Sc extending nearly to the termination of $\mathrm{RI}_{\mathrm{I}}$; only $\mathrm{I}$ or 2 veinlets from $\mathrm{RI}_{\mathrm{I}}$ to costal 
margin beyond Sc; costal space forming the basal, posterior lobation as in rotundum; $\mathrm{R}_{1}$ with one or more distal branches; $\mathrm{CuA}_{2}$ absent as a distinct vein; area between $\mathrm{CuA}$ and $\mathrm{CuP}$ small; cross veins much as in rotundum. Pronotum broad, with curved lateral extensions; anterior border concave; with very little extension; no posterior extension. Head of moderate size.

Holotype: No. 2137, Museum of Comparative Zoology, collected in lower layer of the Elmo limestone by F. M. Carpenter. This consists of a complete insect, showing both fore wings and parts of the body. Unfortunately, the hind wings are overlapped and rest on the abdomen in such a way that their venation cannot be untangled.

This species differs from rotundum and maculosum by its much smaller size, broader fore wing, relatively longer Sc, the apparent loss of $\mathrm{CuA}_{2}$ and the presence of a smaller space between $\mathrm{CuA}$ and $\mathrm{CuP}$.

The preservation of both fore wings enables a comparison of the venation of the two wings in this one specimen. As can be seen in figure IO, there are differences in the branching of all main veins in the two wings, especially of MA, MP, and $\mathrm{CuA}$. In all probability the coalescence of MA with Rs is subject to similar fluctuation, although it occurs in both wings. The prothorax is clearly preserved, showing the pronotum proper and the thin, lateral extensions. As shown in the figure, the extensions are absent posteriorly and are scarcely present anteriorly, although they are well developed laterally. 'This is in contrast to the structure in the liomopterids as well as in the euryptilontids, in both of which the extensions are well developed posteriorly.

The head is preserved in a dorsal view and shows no structural details, apart from indications of small compound eyes.

\section{Family Tococladidae, new family}

Fore wing: costal marginal; wing margin very nearly straight, narrowed basally; Sc extending to about mid-wing, with oblique, unbranched veins leading to margin; similar branches from $\mathrm{R}$ to margin beyond $\mathrm{Sc}$; Rs arising well before mid-wing, with several long branches; $\mathrm{M}$ independent of $\mathrm{R}$ basally; $\mathrm{MA}$ with long, simple branches; MP unbranched; area between $\mathrm{CuA}$ and $\mathrm{CuP}$ traversed by numerous, strong cross-veins, not forming a reticulation; $\mathrm{CuP}$ nearly straight, not extending markedly along posterior margin; no separate vena dividens; anal veins numerous and well defined; cross veins distinct and simple over virtually all the wing, including the 
anal area. Microtrichia and setae absent. Hind wing and body unknown.

This family is probably related to the Ischnoneuridae and Protokollaridae. The very base of the wing is known; a precostal area may have been present. The wing is made distinctive by the extensive development of the radius and the parallel arrangement of the branches of $\mathrm{Rs}$ and $\mathrm{M}$. The basic structure $\mathrm{Cu}$ is different from that of the Oedischiidae and related groups in that all the branches of Rs are markedly convex, without the basal concave vein present in the Oedischiidae and the Carcurgidae. The stem of $M$ is flat and very weak, not strong and convex as in the Blattinopsidae.

\section{Genus Tococladus, new genus}

Fore wing: slender, costal area moderately narrow; Sc ending on $\mathrm{R}_{\mathrm{I}}$, with numerous oblique veinlets; $\mathrm{Rs}_{\mathrm{s}}$ remote from $\mathrm{R}_{\mathrm{I}}$ near midwing but approaching it distally; anterior branch of $M$ forked shortly after origin of $\mathrm{Rs}$, its branches long and simple; several anal veins or main branches.

Type-species: Tococladus rallus, n. sp.

Tococladus rallus, n. sp.

Text-figure I 4

Fore wing: length, $24 \mathrm{~mm}$; width, $7 \mathrm{~mm}$. Rs with six branches; front branch of $M$ coalesced with $\mathrm{Rs}$ for a short distance before diverging posteriorly (possibly an individual fluctuation); IA apparently with three long branches; cross veins widely spaced over most of wing.

Holotype: No. 5866ab, Museum of Comparative Zoology, collected in the lower layer of the Elmo limestone by F. M. Carpenter. This consists of a complete fore wing, well preserved but lacking the very base. The wing, which is preserved with fine wrinkles, was apparently thin and membranous, not coriaceous.

\section{Order Orthoptera}

The Palaeozoic families Oedischiidae, Tcholmanvisiidae and Permelcanidae are now generally regarded as orthopterous, rather than protorthopterous, this view being based mainly on the saltatorial modification of the hind legs and the probable lateral flattening of the body. Of these, only the Oedischiidae are known from the Upper Carboniferous. These early Orthoptera are not extensively repre- 


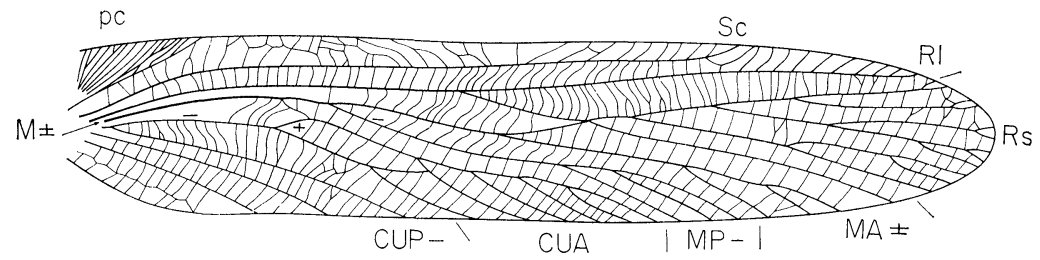

Text-figure 15. Oedischia williamsoni Brongniart. Original drawing, based on type in Inst. Paléont., Paris. pc is the precostal area.

sented in any Permian deposit. In the Elmo limestone there is one genus which appears to belong to the Oedischiidae and which is close to Metoedischia from the Permian of the Soviet Union. There are also representatives of three other families, two of them new.

It should be noted that there are many additional orthopteroids present in the Yale and Harvard collections from the Elmo limestone, almost all of them undescribed. But none of them, so far as can be determined now, belong to the Orthoptera. They will be treated in the next part of this series of papers.

\section{Family Oedischiidae Handlirsch}

Oedischiidae Handlirsch, 1906, p. 700.

Fore wing: usually thin, only slightly coriaceous; precostal space well developed; Sc extending well beyond mid-wing, with several branches; $M$ dividing at about a third of the wing-length from the base into MA, which is not clearly convex, and MP, which is markedly concave; MA usually anastomosed with $\mathrm{Rs}$; $\mathrm{Cu}$ forked near the base, the posterior branch, $\mathrm{CuP}$, strongly concave; the anterior branch $(\mathrm{CuA})$ forking at least once, in part coalescing with a cross vein leading from $M$, and eventually forming several branches which lead to the hind margin; $\mathrm{CuP}$ unbranched; at least three anal veins; cross veins numerous, in some species forming a reticulation in certain parts of the wing. (See text-figure I5)

Hind wing unknown. Body unknown, except for legs; hind legs long and modified for jumping.

This family is known from the Upper Carboniferous of France (Commentry) and Germany and the Permian of USSR and possibly Czechoslovakia. The species described below constitutes the first record of the family in North American deposits.

Unfortunately, almost all specimens of Oedischiids consist of isolated wings. The type-species of Oedischia (williamsoni Brongniart) is represented by two fragmentary specimens showing the fore 


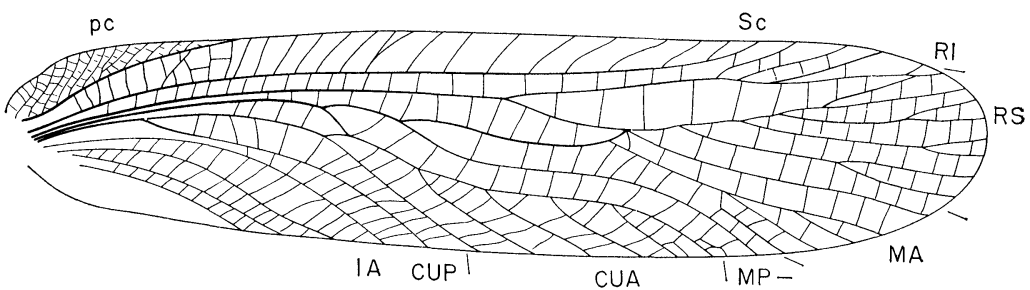

Text-figure 16. Faroedischia recta, n. sp. Drawing based on the holotype (middle part of wing), paratype No. 15638 (base of wing) and paratype no. 15757 (apex of wing).

wings and legs. As noted above, the hind wings are unknown in the family ${ }^{7}$; a small and apparently distorted fragment of a hind wing is preserved in the type of Permoedischia moravica Kukalová, from Czechoslovakia, but this genus can only doubtfully be referred to the Oedischiidae. It has been assumed, probably correctly, that the oedischiid hind wings had an expanded and folded anal area. I have discussed above the peculiarities of the topography of the venation of Oedischia and have given reasons for my present belief that in this family, at least, the short vein connecting the stem of $\mathrm{M}$ to $\mathrm{CuA}$ is a modified cross vein, not a branch of $\mathrm{M}$ or a part of $\mathrm{CuA}$.

\section{Genus Paroedischia, new genus}

Fore wing: shape much as in Metoedischia. Sc extending well beyond mid-wing, longer than in Metoedischia; Rs arising at about mid-wing, free piece of Rs (before anastomosis with $M$ ) longer than in Metoedischia; separation of $\mathrm{CuA}$ and $\mathrm{CuP}$ much later than in Meloedischia; cross veins as in Metoedischia, but without formation of reticulation. Hind wing unknown.

Type-species: Paroedischia recta, n. sp.

On the basis of the fore wing, which is all that is known, this genus seems to be close to Metoedischia but differs in the several respects already noted.

\section{Paroedischia recta, n. sp. Text-figure 16 and Plate 7}

Fore wing: Length of holotype fragment, $20 \mathrm{~mm}$.; width $7 \mathrm{~mm}$.; estimated complete length of wing, $37 \mathrm{~mm}$.; width $7 \mathrm{~mm}$. Precostal space with a series of nearly parallel veinlets, connected by short

\footnotetext{
${ }^{7}$ The restoration of the oedischiid genus Metoedischia given by Martynov (1938, p. 49) was based on specimens of two species, one of which is now placed in the genus Pinegia of the family Tcholmanvissiidae.
} 
cross veins; costal area with a series of straight or nearly straight veinlets, only very rarely branched; RI with several branches distally; Rs with several main branches, each forked; $M$ dividing well before origin of Rs; MP sigmoidally curved; $\mathrm{CuA}$ with 6 terminal branches; space between IA and 2.A widened distally; cross veins as shown in figure .

Holotype: No. 5897ab, M.C.Z., collected by F. M. Carpenter, in lower insect layer at Elmo, Kansas; this consists of the middle part of a well preserved fore wing. Several additional specimens almost certainly belonging to this species are as follows: No. 15757, Peabody Museum, Yale University (collected by C. O. Dunbar), consisting of a distal third of a fore wing; No. 15638ab, Peabody Museum (collected by C. O. Dunbar) ; consisting of the basal quarter of a fore wing; No. 5900, M.C.Z. (collected by F. M. Carpenter), distal half of fore wing; No. 5898, M.C.Z. (collected by F. M. Carpenter), basal third of fore wing; No. 5899, M.C.Z. (collected by F. M. Carpenter), distal fragment of fore wing; No. 5896, M.C.Z. (collected by F. M. Carpenter), distal fragment of fore wing.

The fragmentary nature of these specimens is strongly indicative of unusually delicate wings, almost certainly membraneous, rather than coriaceous. A composite drawing of the fore wing of recta is included in figure 16 ; the central part of the wing is drawn from the holotype; the basal and distal portions are based on specimens numbered 15638 and 15757 , respectively.

The venation of this insect is clearly subject to much variation, the number and precise arrangement of branches being different to some degree in all specimens.

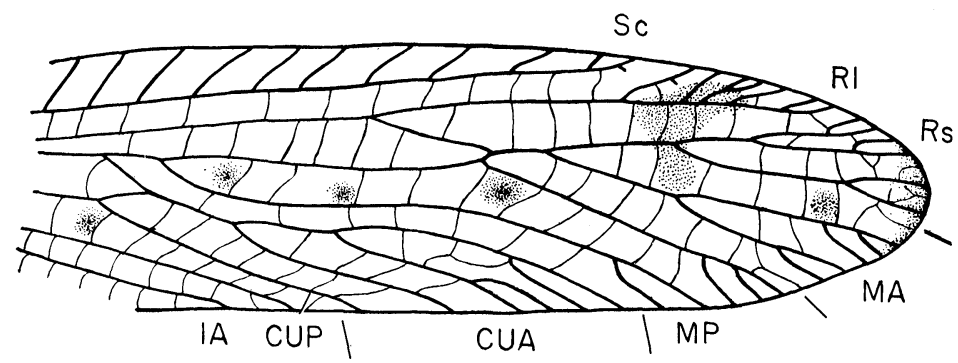

Text-figure 17. Paroedischia maculata, n. sp. Drawing of fore wing (holotype). 


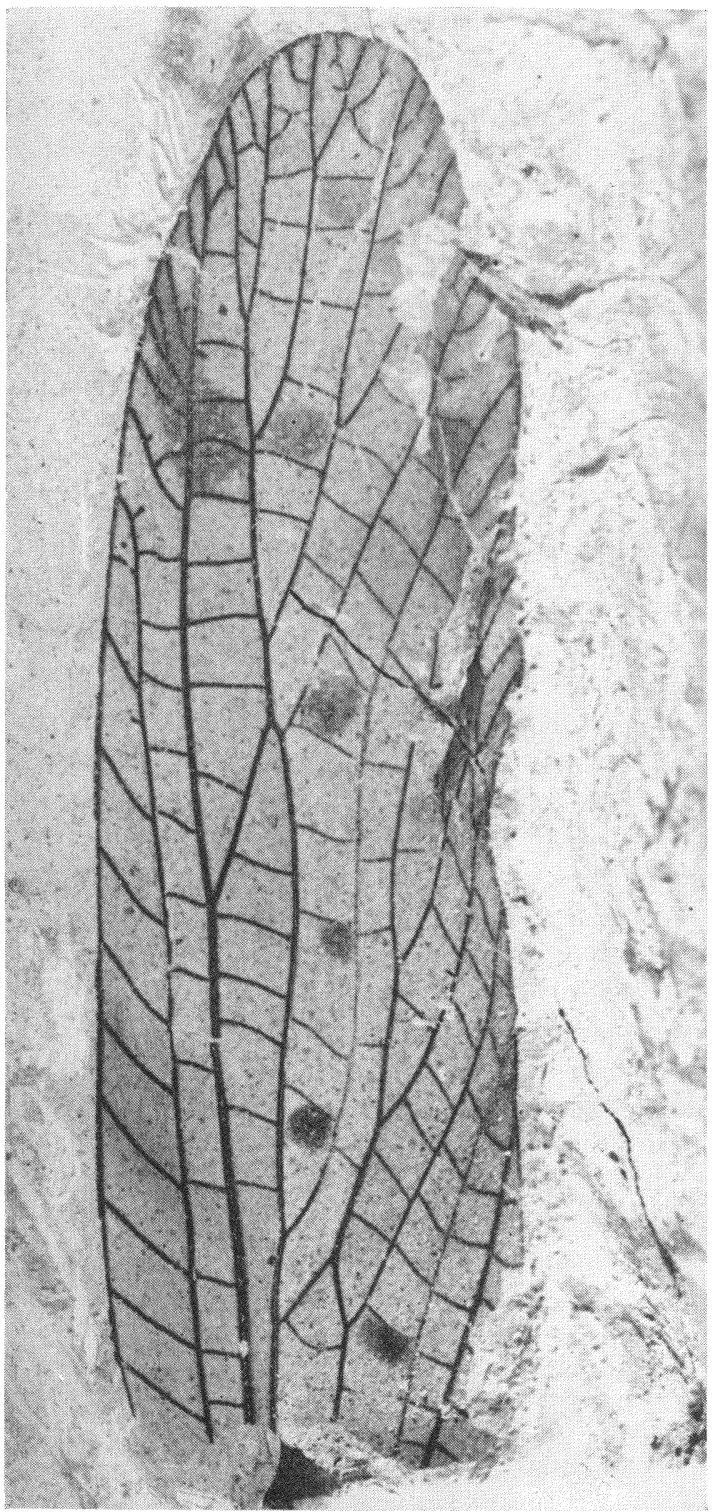

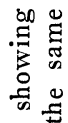

领

용

드

吾

茴?

ปั

넝 ส

हु

$\sum 0$

m.

虽茨

之을

造范

옹

㟧

동.

कू है

:

ธ

2.9

के

म

ปี

ธ.

$\therefore$

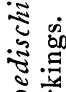
है है है 


\section{Paroedischia maculata, n. sp. Text-figure 17}

Fore wing: length, as preserved, $20 \mathrm{~mm}$. width, $7 \mathrm{~mm}$.; estimated complete length, $30 \mathrm{~mm}$. Venation so far as known like that of recta, except that the main veins are almost consistently forked at the wing margin, the branching of $\mathrm{R}$ is less, the main veins are thicker, and the cross veins are thinner and more irregular. In addition the wing has several distinct maculations, as shown in the photograph, plate 4. The wing of recta shows no signs of markings of any kind.

Holotype: No. 5873ab, Museum of Comparative Zoology (Collected by F. M. Carpenter), in the lower layer of the Elmo limestone; this consists of a distal two-thirds of a wing, which is somewhat wringled along the posterior border but otherwise very well preserved.

\section{Family Permelcanidae Sharov}

\section{Permelcanidae Sharov, 1962, p. 112.}

Fore wing: membranous or very weakly coriaceous. Precostal area well developed but not forming a prominent bulge, extending about one-fourth wing length from base; Sc extending slightly beyond mid-wing; $\mathrm{R}$ distinct from Sc basally; $\mathrm{Rs}$ arising near or just beyond mid-wing, usually anastomosing with a branch of MA for at least a short distance; $R$ s and $M$ with at least two terminal branches; $\mathrm{CuA}$ as in the Oedischiidae, with several terminal branches; $\mathrm{CuP}$ close to IA; IA with several veinlets leading to the hind margin; $2 \mathrm{~A}$ and $3 \mathrm{~A}$ much shorter. Cross veins much fewer than in the Oedischiidae, not forming a true reticulation.

Specimens showing both fore and hind wings have not been found, but isolated portions of hind wings, consisting mainly of the remigium in each case and probably belonging to this family, have been described by Sharov. In these hind wings the costa is short and submarginal; Sc, RI, Rs and $M$ are essentially as in the fore wing; an anal area was presumably present although only a suggestion of one is visible in the fossils. The body structure is unknown.

Three previously described genera belong here: Promartynovia Tillyard, from the Elmo limestone, Kansas; and Permelcana Sharov and Proelcana Sharov, from upper and lower Permian deposits, respectively, in the USSR.

\section{Genus Promartynovia Tillyard}

Promartynovia 'Tillyard, 1937, Amer. Journ. Sci., 33 :99.

Permelcana Sharov, 1962, Paleont. Journ. 2:114.

Fore wing: costa usually consisting of two or more distinct 
branches arising from the wing base; Rs arising just before the end of $\mathrm{Sc}$; $\mathrm{CuA}$ with several terminal branches; IA extending well beyond $2 \mathrm{~A}$ and sending several short branches to the hind margin; cross veins usually straight, only rarely branched. Pterostigmal and apical areas of wing pigmented.

Type-species: Promartynovia venicosta Tillyard.

I have been unable to find sufficient differences between Promartynovia Tillyard and Permelcana Sharov to justify generic separation. Promarcynovia was very incompletely known to Tillyard, who placed it in the order Neuroptera, and his description of $P$. venicosta was unsatisfactory, for the reasons given below. The typespecies (sojanense Sharov) of Permelcana Sharov is known by a nearly complete fore wing, which lacks only the apical region. Sharov had little reason to associate his fossil from the Upper Permian of the USSR with Promartynovia, although I had pointed out in 1943 (p. 6I) that the latter genus was orthopteroid not neuropteroid. I strongly suspect, also, that Proelcana Sharov, based on an apical fragment (uralica Sharov) from Lower Permian deposits of Tchekarda, USSR, will turn oui to be a synonym of Promartynovia; the amount of anastomosis between Rs and M, and the detailed arrangement of the branches of these veins, used by Sharov as generic characters, are highly variable within this group of orthopteroids.

\section{Promartynovia venicosta Tillyard \\ Text-figure 18}

Promartynovia vencosta Tillyard, 1937, Amer. Journ. Sci., 33:100; fig. 6 (Order Neuroptera, family Martynoviidae).

Fore wing: length II mm.; width $2.6 \mathrm{~mm}$.; front margin apparently slightly concave; costa consisting of two main branches leading from wing base, the posterior one simple, the other forming

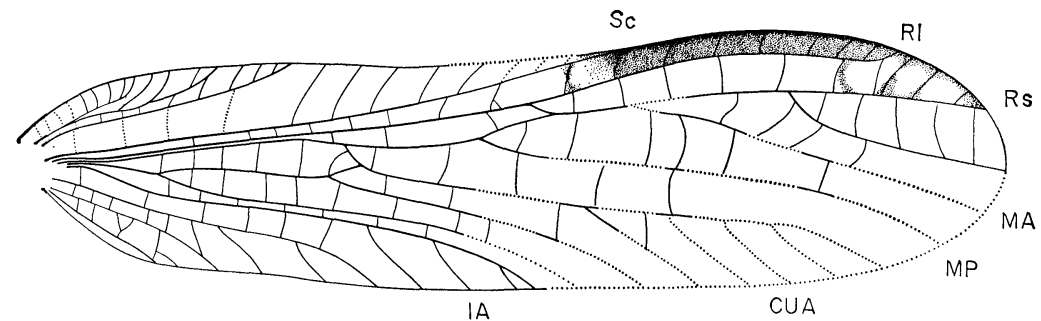

Text-figure 18. Promartynovia venicosta Tillyard. Drawing of fore wing, based on hoiotype in Peabody Museum, Yale University. 
a complex of several branches; costal veinlets oblique, long, unbranched; Rs with two branches; MA anastomosed with Rs for a short distance; MP apparently unbranched.

Holotype: No. 15594, Peabody Museum, Yale University. This specimen, when studied by Tillyard, had not been completely cleaned; it was known to him only by the base of the wing. Removal of matrix has revealed the greater part of the rest of the wing, as shown in figure I8; some parts of the posterior margin of the wing are missing but they are not critical for the determination of the species.

In his figure of the fossil, Tillyard omitted the weakly developed $\mathrm{CuP}$, which arises from $\mathrm{Cu}$ basally and runs closely parallel to IA. It can be seen clearly in the specimen, however, with the aid of lowangle illumination. Tillyard's assignment of Promartynovia to the Neuroptera (Sialoidea) was made with some doubt; actually he placed the genus in the family Martynoviidae, now included in the extinct order Diaphanopterodea. The similarity of the fore wing of venicosta to that of sojanense Sharov is really striking. They are of comparable size, have a similar venation and even possess the identical pigmentation of the pterostigmal area.

\section{Family Parelcanidae, new family}

Fore wing: more coriaceous than in Oedischiidae; precostal area torming a prominant bulge; Sc apparently extending well beyond mid-wing; Rs (so far as known) arising slightly beyond mid-wing, anastomosed with a branch of $M$ for a short distance; $\mathrm{CuA}$ and $\mathrm{CuP}$ as in Oedischiidae; IA nearly straight; cross veins about as numerous as in Oedischiidae. Hind wing and body unknown.

This family, which is apparently more closely related to the Oedischiidae than to the Permelcanidae, is characterized mainly by the prominance of the precostal area and by the coriaceous nature of the fore wing.

\section{Genus Parelcana, new genus}

Fore wing: costa usually consisting of two distinct branches, the anterior one giving rise to a series of radiating veins, the posterior one forked; at the level of end of precostal area, the costal space is about as wide as the space between $\mathrm{R}$ and $\mathrm{Sc}$; termination of IA close to end of $2 \mathrm{~A}$; cross veins close together, uniformly distributed; no reticulation formed (at least in basal half of wing).

Type-species: Parelcana dilatata, n. sp. 


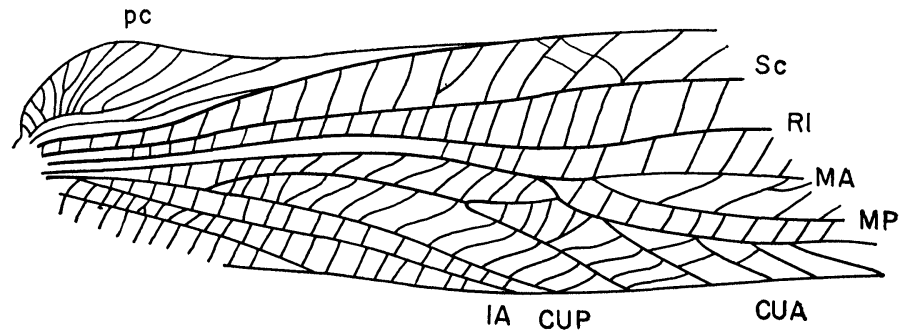

Text-figure 19. Parelcana dilatata, n. sp. Drawing of fore wing (holotype).

Parelcana dilatata, n. sp.

Text-figure 19

Fore wing: length of preserved part $19 \mathrm{~mm}$; width, $5 \mathrm{~mm}$.; estimated length of complete wing, $36 \mathrm{~mm}$.; costal veinlets slightly oblique, mostly unbranched; branches of $\mathrm{CuA}$ short. Details of venation shown in figure 19.

Holotype: No. 6304 ab, Museum of Comparative Zoology' (collected by F. M. Carpenter in lower layer of Elmo limestone). This type consists of a well preserved basal half of a fore wing.

The precostal area of this wing is unusually prominent. Although the wing is incomplete, that part which is preserved seems to be definitely coriaceous; the cross veins are preserved as distinct ridges, which are especially prominent when observed under oblique light.

\section{Genus Petrelcana, new genus}

Fore wing: distinctly coriaceous; slender. Precostal area not so long or so broad as in Parelcana, but projecting beyond the line of the anterior margin of the wing; costa little-known, irregularly formed; R I with several oblique, almost longitudinal veinlets beyond the end of Sc; at level of end of precostal area, costal space much wider than space between $S c$ and $R$; termination of $\mathrm{IA}$ well beyond the end of $2 \mathrm{~A}$; cross veins more widely separated than in Parelcana and more irregular, forming a coarse reticulation in parts of the anal area.

Type-species: Petrelcana elongata, $\mathrm{n} . \mathrm{sp}$.

\section{Petrelcana elongata, n. sp. Text-figure 20}

Fore wing; length, as preserved, $33 \mathrm{~mm}$.; width $7 \mathrm{~mm}$.; estimated complete length, $40 \mathrm{~mm}$.; veinlets widely separated and irregular in 


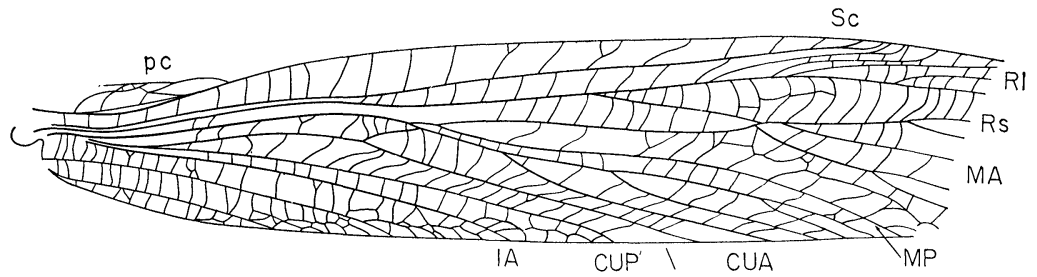

Text-figure 20. Petrelcana elongata, n. sp. Drawing of fore wing (holotype).

most of costal area; cross veins between $\mathrm{R}_{\mathrm{I}}$ and $\mathrm{Rs}$ sigmoidal and parallel; branches of $\mathrm{CuA}$ long, extending beyond the level of anastomosis of Rs with $M$.

Holotype: No. 6306, Museum of Comparative Zoology, collected by F. M. Carpenter in the lower layer of the Elmo limestone. This consists of a nearly complete fore wing, lacking only the apical region. The fossil is very well preserved and shows definite indications of pigmentation along almost the entire length of $\mathrm{R}$ and $\mathrm{R}_{\mathrm{I}}$, the pigmentation broadening out to include surrounding areas after the origin of Rs. The precostal area is not entirely known, although in the specimen it clearly projects beyond the rest of the wing margin; whether or not it forms as noticeable a bulge as in Parelcana cannot be determined. The family assignment of this genus may need to be changed when the form of the costa is known.

\section{REFERENCES}

BOLTON, H.

1925. Insects from Coal Measures of Commentry. Brit. Mus., Fossil Insects, $2: 1-56$.

Carpenter, F. M.

1935. The Lower Permian insects of Kansas. Part 7. The Order Protoperlaria. Proc. Amer. Acad. Arts Sci. 70:103-146.

1943. The Lower Permian insects of Kansas. Part 9. The Orders Neuroptera, Raphidiodea, Caloneurodea and Protorthoptera, with additional Protodonata and Megasecoptera. Proc. Amer. Acad. Arts Sci. 75:55-84.

1950. The Lower Permian insects of Kansas. Part 10. The Order Protorthoptera: the Family Liomopteridae and its relatives. Proc. Amer. Acad. Arts Sci. 78 (4):185-219.

1954. Key to extinct families of insects. In Brues, C. T., A. L. Melander and F. M. Carpenter, Classification of Insects. Bull. Mus. Comp. Zool. $108: 777-827$.

Comstock, J. H.

1918. The Wings of Insects. Comstock Publ. Co. 
Comstock, J. H. and Needham, J. G.

1898-99. The Wings of Insects. Amer. Nat. vols. 32, 33. (A series of 23 papers).

Fraser, F. C.

1931. A note on the fallaciousness of the theory of pretracheation of the wing venation of Odonata. Proc. Roy. Ent. Soc. London, 13: 60-70.

GUTHöкL, P.

1936. Neue Beiträge zur Insekten-Fauna des Saarcarbons. Sencken. 18: Zlb. $72: 1-51$.

HAGEN, H. A.

1870 Ueber rationelle Benennung des Geäders in den Flügeln der Insekten. Stett. Ent. Zeitung 31:316-320.

HAUPT, H.

1941. Die ältesten geflügelten Insekten und ihre Beziehungen zur Fauna der Jetztzeit. Z. Naturw. 94: 60-121.

HENKE, K.

1953. Die Musterbildung der Versorgungssystem in Insektenflügel. Biol. Zlb. $72: 1-51$.

HOLDSWORTH, R.

1940. Histology of the wing pads of the early instars of Pteronarcys proteus Newman. Psyche, 47:112-120.

1941. The wing development of Pteronarcys proteus Newman. Journ. Morphology, $70: 431-461$.

Kukalová, J.

1959. On the family Blattinopsidae Bolton, 1925. Roz. ceskosl. acad. véd., 69 (1): 1-27.

1965. Permian Protelytroptera, Coleoptera and Protorthoptera (Insects) of Moravia. Sborník geol. véd. pal. 6:61-98.

LAMEere, A.

1922. Sur la nervation alaire des insectes. Bull. Class Sci. Belgium, 1922:138-149 (transl. Psyche 30:123-132, 1930).

LESTON, D.

1962. Tracheal capture in ontogenetic and phylogenetic phases of insect wing development. Proc. R. Ent. Soc. Lond. (A) 37:135-144.

Martynov, A. V.

1924. Sur l'interpretation de la nervuration et de la tracheation des ailes des Odonates et des Agnathes. Rev. Russe d'Ent., $18: 145-174$. (transl. Psyche $37: 245-280,1930)$.

1937. Permian fossil insects from Kargala and their relationships. Trav. Inst. Paléoni. Acad. Sci. URSS, $7: 1-92$.

1938. Etudes sur l'histoire géologique et de phylogénie des ordres des insectes (Pterygota). Trav. Inst. Paléont. Acad. Sci. URSS 7: 1-150.

NeEdham, J. G.

1935. Some basic principles of insect wing-venation. Journ. N. Y. Ent. Soc. $43: 113-129$.

1951. Prodrome for a manual of the dragonflies of North America, with extended comments on wing venation systems. Trans. Amer. Ent. soc. $77: 21-62$. 
REDTENBACHER, J.

1886. Vergleichende Studien über das Flügelgeäder der Insekten. Ann. des k.k. nat. Hofmuseums 1. (3): 153-232.

ROHDENDORF, B. B., ET AL.

1962. Osnovy Paleontologii. Insecta. pp. 1-373. Akad. Nauk. SSSR. SCUDDER, S. H.

1885. Palaeodictyoptera: or the affinities and classification of Paleozoic Hexapoda. Mem. Bost. Soc. Nat. Hist. 3:319-351.

SELlards, E. H.

1909. Types of Permian insects. Part 3. Amer. Journ. Sci. 27:151-173. Sharov, A. G.

1960. On the system of the Orthopterous Insects. Internat. Cong. Ent., Wien, 1960 (1): 295-296.

1962. A new Permian family Permelcanidae (Orthoptera). Pal. Journ. 2:112-116.

SMART, J.

1956. A note on insect wing veins and their tracheae. Quart. Jour. Micros. Sci. 97 (4) : 535-539.

SPEITh, HermanN.

1932. A new method of studying the wing veins of the mayflies and some results obtained therefrom. Ent. News, 43:103.

Tillyard, R. J.

1923. The wing-venation of the order Plectoptera or mayflies. Journ. Linn. Soc. Zoology, $35: 143-162$.

1927. Kansas Permian insects. Part 17. The Order Megasecoptera and additions to the Palaeodictyoptera, Odonata, Protoperlaria, Copeognatha and Neuroptera. Amer. Journ. Sci. $33: 82-110$.

1928. The new order Protoperlaria. Amer. Journ. Sci. 16:185-220. WATERLot, G.

1934. Bassin houiller de la Sarre et de la Lorraine. ii. Faune fossile. Etudes Gites Min. Fr: 1934. 111-221; 269-273. 

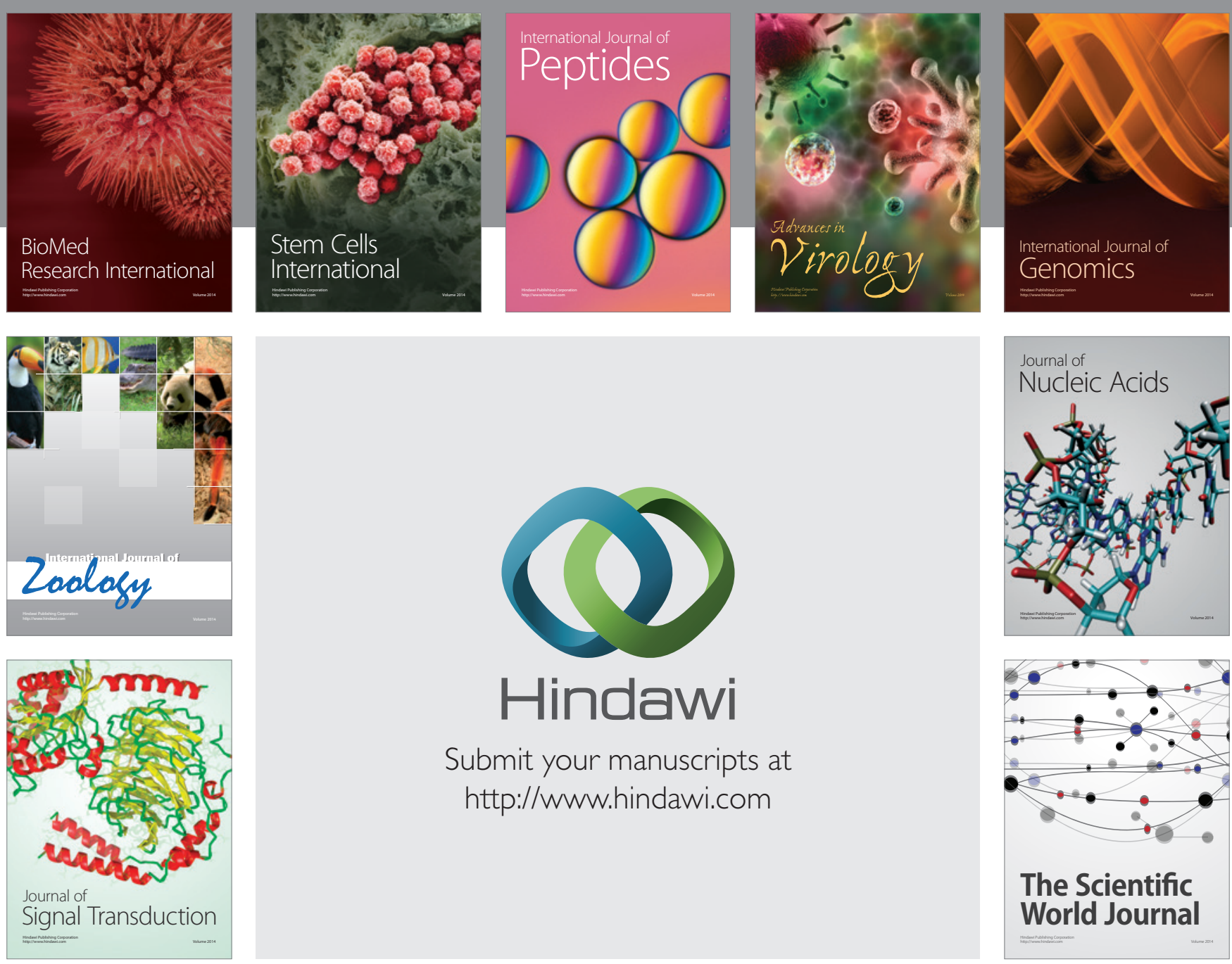

Submit your manuscripts at

http://www.hindawi.com
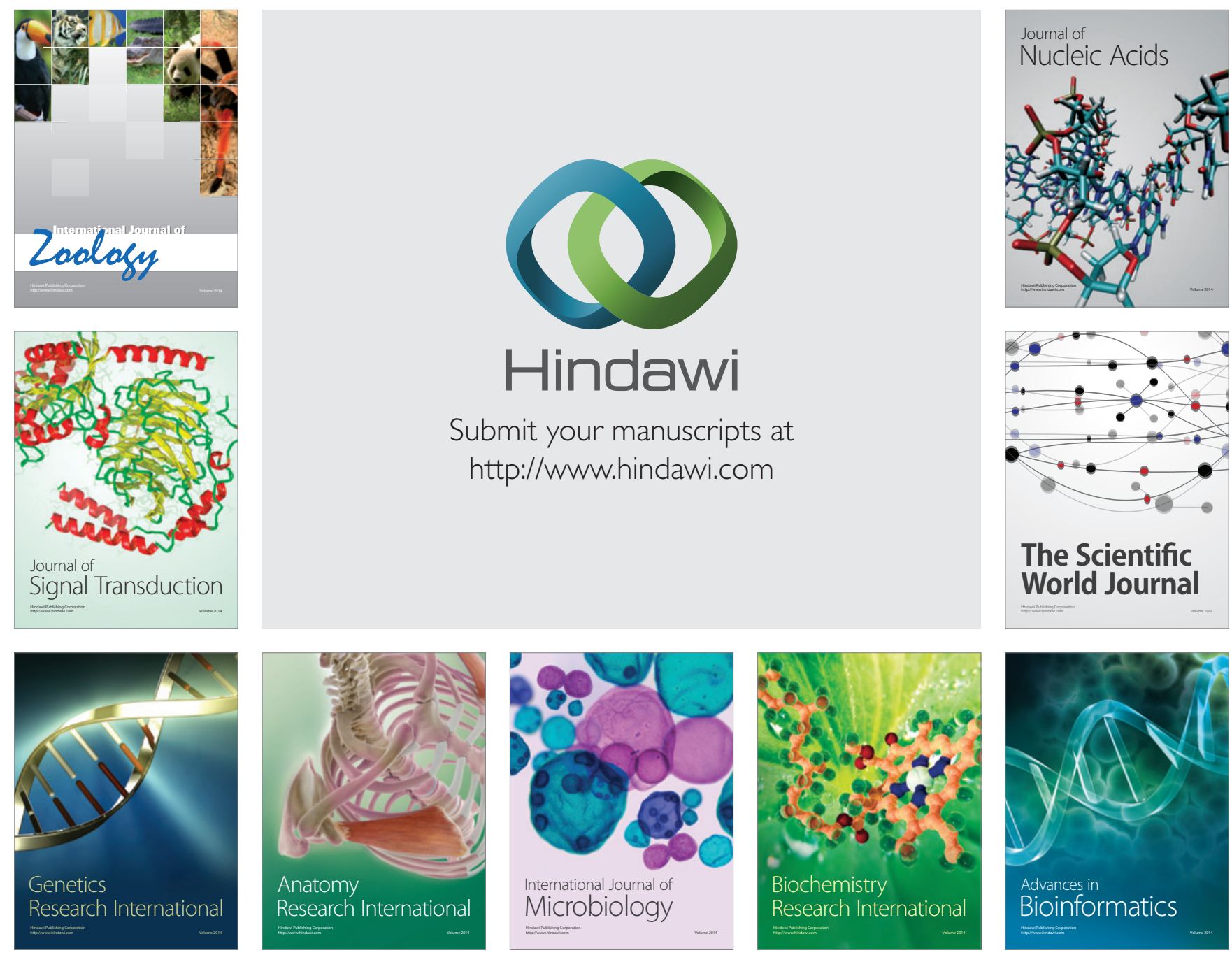

The Scientific World Journal
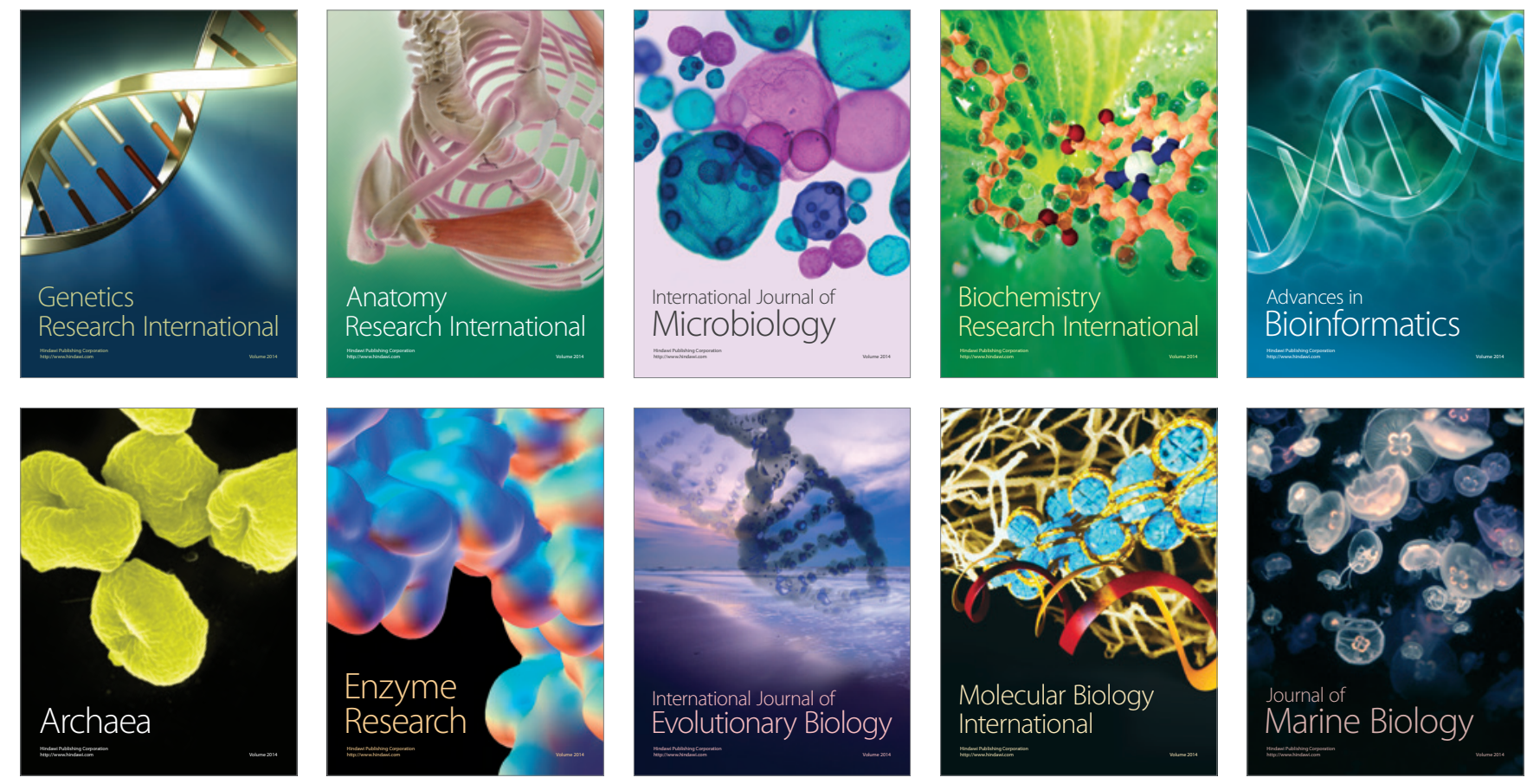